\title{
Audit committees' independence and the information content of earnings announcements in Western Europe
}

\author{
Cédric PORETTI \\ EHL Lausanne, HES-SO, University of Applied Sciences, Western Switzerland
}

\author{
Alain SCHATT* \\ HEC Lausanne \\ Liesbeth BRUYNSEELS \\ KU Leuven
}

\begin{abstract}
We examine whether the percentage of independent members sitting on the audit committee, in different institutional settings, impacts the market reaction (measured by the abnormal stock returns variance and the abnormal trading volume) to earnings announcements. For our sample composed of more than 7'600 earnings announcements made by European firms from 15 countries between 2006 and 2014, we find that the market reactions to earnings announcements are significantly larger when the audit committee is more independent in countries with weak institutional setting. Our results generally hold after controlling for numerous methodological issues. We conclude that more independent audit committees are substitutes for weak institutions to increase the credibility of earnings announcements. Our results should be of great interest for European regulators who recently introduced new requirements for public firms regarding audit committees' independence.
\end{abstract}

\section{Keywords}

Audit committee; Europe; Earnings announcements; Market reaction.

The authors would like to thank the two anonymous reviewers, Paul André, James Hansen, Michel Magnan, Bernard Raffournier, and the participants of the 2017 International Conference on Assurance and Governance in Gainesville and the 2017 AAA Auditing section meeting in Orlando for their insightful suggestions.

*Correspondence address: Alain SCHATT, HEC Lausanne, Dorigny-Anthropole, 1025 Lausanne, Switzerland.Email: alain.schatt@unil.ch 


\section{Audit committees' independence and the information content of earnings announcements in Western Europe}

\section{Introduction}

Prior research on investor reactions to earnings announcements has shown that the institutional setting significantly influences the information content of these announcements (e.g. DeFond et al., 2007). However, this literature does not consider the role of firm-specific governance mechanisms and the role they play in enhancing earnings credibility. We posit that governance mechanisms such as independent audit committees have a significant influence on earnings credibility and that this relationship varies across institutional settings. Specifically, we show that audit committees play an especially important role in enhancing earnings credibility in countries with weaker accounting standards enforcement, or weaker legal protection of investors. As such we are the first to investigate the joint effect of firm-level governance mechanisms, such as the audit committee, and the institutional context on earnings credibility.

The European setting provides a unique opportunity to investigate investor perception of audit committee effectiveness in various institutional contexts. Since 2006, European public-interest entities ${ }^{1}$ must establish an audit committee that includes at least one independent member (European Commission, 2006). Some companies, however, have voluntarily decided to hire $100 \%$ of independent members on the audit committee, which ultimately results in large disparities in the composition of European audit committees.

\footnotetext{
1 Those entities are defined as "entities governed by the law of a Member State whose transferable securities are admitted to trading on a regulated market of any Member State.”

http://eur-lex.europa.eu/LexUriServ/LexUriServ.do?uri=CONSLEG:2006L0043:20080321:EN:PDF
} 
Such variance does not exist anymore in the US, because the Sarbanes-Oxley Act obliges public firms to appoint $100 \%$ of independent members in the audit committee. In 2014, the European legislation was amended. The European commission decided that at least half (50\%) of the members sitting on the audit committee must be independent. This new regulation, which will enter into force in 2016, does not affect our study that covers the period 2006 to 2014 .

This study focuses on investor reactions to annual earnings announcements, which crucially depends on the credibility of the earnings. Indeed, investors must believe that earnings reflect the true performance of the company, which is notably the case when managers (or insiders) have not managed earnings (Healy and Wahlen, 1999; Leuz et al., 2003; Dechow et al., 2010). Since the credibility of earnings is not directly observable, investors may try to assess it by focusing on some observable factors. First, institutional characteristics may improve the credibility of earnings, such as the legal protection of investors (Ball et al., 2000; Leuz et al., 2003). Second, various firm-specific characteristics may also improve the credibility of earnings, especially audit committees composed of independent members (Bédard and Gendron, 2010; DeFond and Zhang, 2014). However, it is likely that these two factors are related. Indeed, in weak institutional contexts, managers have more incentives to distort financial information to acquire private benefits (Leuz et al., 2003; Pevzner et al., 2015). In such contexts, investors may rely on firm-specific substitutes, such as the audit committee, to assess the credibility of earnings. The role of the audit committee might, however, also be enhanced in a context where institutions are stronger and enable this committee to fulfill its duties in a more efficient way. Such effect is found by Becher and Frye (2011), who show that more 
efficient governance practices are related to stronger regulation. Consequently, audit committee effectiveness and institutional strength might complement each other in reinforcing investor confidence in reported earnings, or they might act as substitutes. This article specifically studies the role played by audit committees in enhancing earnings credibility in different institutional settings, by focusing on the impact of the audit committee's independence on the market reaction to earnings announcements in Europe.

Several studies have already shown that financial markets reaction to earnings announcements differ across countries. DeFond et al. (2007) find that annual earnings announcements are more informative in countries with higher earnings quality and stronger investor protection institutions. Landsman et al. (2012) examine whether the information content of earnings announcements increases in countries following mandatory IFRS adoption. They show that the information content increased in countries that mandated adoption of IFRS compared to countries that maintained domestic accounting standards. However, the effect of mandatory IFRS adoption also depends on the strength of legal enforcement in the adopting country. Finally, Pevzner et al. (2015) investigate the effect of societal trust on investor reactions to corporate earnings announcements. They find that investors reactions to earnings announcements are significantly higher in more trusting countries, but the positive effect of societal trust on investors reactions is more pronounced when a country's investor protection is weaker, suggesting that trust acts as a substitute for formal institutions.

These studies emphasize the role of institutions to explain the market reaction to earnings announcements. Therefore, such country-level studies provide little information about the role of firm-specific mechanisms that increase the credibility of earnings and, 
therefore, may also explain the market reaction in a given institutional context. In particular, these studies do not consider the role of audit committees, which are likely to affect managers' financial reporting choices and, therefore, may increase earnings credibility through two main channels (Bédard and Gendron, 2010; DeFond and Zhang, 2014). First, these committees are responsible for the selection of external auditors, the validation of their workload and the negotiation of audit fees. Second, audit committees also oversee the internal control of the firm.

Various studies show that the effectiveness of the audit committee depends on its composition. More specifically, the independence of such committees' members seems to play a crucial role when considering the quality of financial reporting. Indeed, more independent committees are associated to lower abnormal accruals (Carcello et al., 2003; Bédard et al., 2004; Klein, 2002; Peasnell et al., 2005; Koh et al., 2007) and fewer restatements (Beasley et al., 2000; Abbott et al., 2000; Pucheta-Martínez et al., 2007). Since most studies focus on the US market, which is characterized by specific institutions (e.g. strong investors' legal protection), it is not clear whether independent audit committees are also efficient mechanisms in countries with different institutional contexts.

To the best of our knowledge, no study has yet analysed the role of independent audit committees in different institutional settings. The academic literature has focused on the role of external auditors, especially the role of Big Four auditors. For instance, Francis and Wang (2008) find that earnings quality increases for firms with Big Four auditors when a country's investor protection regime gives stronger protection to investors. Fung et al. (2016) show that auditors are more likely to issue modified opinions to their economically important clients and this association is stronger in countries with 
stronger legal regimes. Choi and Wong (2007) show that Big Five auditors play a more important role in countries with weak institutions compared to countries with strong ones. Finally, Choi et al. (2008) develop a model in which national legal environments play a crucial role in determining auditor effort and audit fees. Their empirical study supports this prediction. Overall, the role of external auditors seems affected by the institutional environment, but it is not totally clear how these two mechanisms are associated. One potential reason might lie in the fact that these studies do not take into account internal control. In that case, the analysis of independent audit committees is particularly interesting since they oversee internal control and external control.

To analyse the impact of the independence of audit committees on the market reaction to earnings announcements in different institutional contexts, we built a sample comprising 7'656 earnings announcement by 1'420 listed companies in 15 European countries. We find that the proportion of independent members sitting on the audit committee is positively and significantly associated with the market reaction to earnings announcements, which is measured with abnormal stock returns variance and abnormal trading volumes. In addition, the institutional context proxied by the Brown et al. (2014) audit and enforcement index is also positively associated with the market reaction. However, the interaction between the proportion of independent members in the audit committee and the institutional context is negatively related to the market's reaction to earnings announcements. Thus, the independence of the audit committee has a stronger impact on investors' reaction to earnings announcements in countries with weaker institutional contexts. This result leads us to conclude that the audit committee's independence and the institutional context are substitutes. 
We then decompose the Brown et al. (2014) index into its two sub-indices: the audit working environment and the enforcement of accounting standards. The underlying idea is that only one of these two sub-indices might be relevant to explain the substitution between audit committee's independence and weak institutions. We find that both subindices have a positive impact on investors' reaction. The independence of the audit committee has a stronger impact on investors' reaction to earnings announcements in countries with either weaker audit working environment, or weaker enforcement of accounting standards. We therefore conclude that our main result is not driven by one sub-index.

Five additional tests support and extent our main results. First, in weak institutional settings, we highlight that the increase in the perceived credibility of earnings by financial markets is mostly due to fully independent audit committees, but our results are not conditional on the size of the audit committee. In other words, the new European regulation (i.e. at least $50 \%$ of independent members instead of at least one independent member) should be beneficial to investors in weak institutional settings, but we argue that the new regulation is not going far enough. Our findings regarding the importance of fully independent members are in line with those obtained in the US by Bronson et al. (2009). Second, we consider an alternative measure of the market reaction to earnings announcements (the cumulative abnormal returns) and show that our results remain broadly unchanged. Third, we analyse whether the substitution effect is driven by the proxy used for the institutional context, namely the Brown et al. (2014) index. For this additional test, we use two indices from the World Bank Group (Worldwide Governance Indicators). We also find a significant substitution effect between audit committee's 
independence and weak institutions. Thus, our results are not driven by the proxy used for the institutional context. Fourth, our results might be driven by a "UK-effect", as it represents $43.1 \%$ of our sample. We control for this limitation by running all our tests without UK firms and show that our results still hold. Finally, we account for the potential endogeneity of the audit committee composition, by using the ownership structure as an instrumental variable in a two-step regression. Our results remain unchanged, but their significance decreases.

Overall, we contribute to the literature in two ways. First, we demonstrate that financial markets attach some importance to the presence of a fully independent audit committee in countries where the institutional context does not favor the credibility of earnings. Although costs may be associated with the presence of a fully independent audit committee (e.g. DeFond and Zhang, 2014), it seems that some benefits are also associated with the appointment of $100 \%$ of independent members in such countries. Hence, the adoption of the recent European regulation regarding the proportion of independent members on the audit committees is not likely to produce large positive effects. Since it is possible for each European country to introduce stricter rules than those proposed by the European Commission, our results support the idea that the regulators in countries with weak institutions should impose fully independent audit committees (i.e. 100\% of independent members).. Second, this article also contributes to the literature analysing the relevance of earnings for some European public firms. More specifically, we highlight a positive reaction of European markets to the announcement of earnings, but the scale of this reaction depends on country-level factors (Ball et al., 2000; Leuz et al., 2003; André et al., 2015) and firm-level factors. 
The rest of this article is organized as follows. In the second section, we present our research design. The third section is devoted to the results. The robustness tests are presented and discussed in the fourth section. We conclude in a final section.

\section{Research design}

\subsection{The sample}

To analyse the relative role of audit committees and institutions on the market reaction around earnings announcements, we use a sample of 7'656 firm-year earnings announcements for 1'420 different firms. To construct this sample, we first select all nonfinancial firms available in the Boardex database between 2006 and 2014 for 15 countries in Western Europe. We only retain firms for which there are at least 3 years of corporate governance data in a row, especially concerning the existence and composition of the audit committee. Second, we collect prices, volumes, expected earnings per share (EPS), EPS announcement dates, and control variables on Datastream and IBES. Third, we also collect EPS announcement dates on the Capital IQ database, to check the accuracy of the dates provided by Datastream. When we find a difference, we use the first date provided in the two databases. Finally, we only retain firms that use International Financial Reporting Standards (IFRS) during the corresponding year, and we drop all firm-years for which we do not have the various variables. These different steps are summarized in table 1.

\section{[ INSERT TABLE 1 ]}


Table 2 shows the distribution of observations by country and by year. More than $66 \%$ of the sample comes from three countries: the UK (43.1\%), France (14.4\%) and Germany (8.6\%). Since the UK represents a large proportion of the sample, we consider this issue in an additional analysis (section 4.3. of the paper). Regarding the distribution of observations across years, we have a minimum number of earnings announcements in 2006 (551) and a maximum number in 2011 (989).

\section{[ INSERT TABLE 2 ]}

\subsection{The models}

To analyse the role of the independence of the audit committee in market reactions to earnings announcements, we test the following models:

$$
\begin{aligned}
& M R_{i}=\alpha_{0}+\alpha_{1} * I N D E P_{-} A C_{i}+\alpha_{2} * I N S T I T_{-} C O N T E X T_{i} *+\sum_{1}^{k} \alpha_{i} * \text { Controls }_{i}+\varepsilon_{i} \\
& M R_{i}=\alpha_{0}+\alpha_{1} * I N D E P_{-} A C_{i}+\alpha_{2} * I N S T I T_{-} C O N T E X T_{i} *+\alpha_{3} * I N D E P_{-} A C_{i} * I N S T I T_{-} C O N T E X T_{i}+ \\
& \sum_{1}^{k} \alpha_{i} * \text { Controls }_{i}+\varepsilon_{i} \\
& M R_{i}=\alpha_{0}+\alpha_{1} * I N D E P_{-} A C_{i}+\sum_{1}^{k} \alpha_{i} * \text { Controls }_{i}+\varepsilon_{i}
\end{aligned}
$$

In these models, the dependent variable $\left(M R_{i}\right)$ is the market reaction to annual earnings announcements. We use two measures for the market reaction: the abnormal stock returns variance (AVAR) and the abnormal trading volume (AVOL). The independent variable INDEP_AC is the percentage of independent members in the audit committee. The independent variable INSTIT_CONTEXT captures the strength of the institutional environment. Controls is a vector of control variables including the surprise, the size of the announcing firm, the leverage, the market-to-book, the announcement of a loss, the presence of Big 4, earnings management, the reporting lag, cross-listing, the experience 
of the audit committee members, the size of the audit committee and the size of the board. We define all variables in the next sub-section.

In the three models, we expect $a_{1}$ to be positive if the independence of the audit committee increases the credibility of the earnings and, therefore, the magnitude of the market reaction. In line with Ball et al. (2000), Leuz et al. (2003) and Landsman et al. (2012), we also expect $a_{2}$ (in the first and the second models) to be positive as stronger institutions should increase the credibility of earnings and, thus, the market reaction to earnings announcements. In the second model, $a_{3}$ positive would support the fact that the two mechanisms (the independence of audit committees and the strength of the institutional context) are complementary, whereas $a_{3}$ negative would prove that the two mechanisms are substitutes. In other words, if $a_{3}$ is positive (negative), the impact of more independent audit committees on the market reaction to earnings announcements is stronger (weaker) when the institutional context is stronger.

To control the robustness of our results, we also split the full sample into two subsamples and test model 3. The first subsample includes European countries with institutions that improve the credibility of earnings (which we call "Strong institutions"). The second sample includes European countries with institutions that do not promote the credibility of earnings (which we call "Weak institutions"). If $a_{1}$ is positive only in the first sub-sample, then we can conclude that these two mechanisms (the independence of audit committees and strong institutions) are complementary to improve the credibility of earnings and, therefore, to increase the market reaction. However, if $a_{1}$ is positive only in the second sub-sample, then we can conclude that these two mechanisms (independence of audit committees and strong institutions) are substitutes. In other words, 
the independence of the audit committee plays a key role to improve the credibility of earnings in countries with weak institutions.

\subsection{The variables ${ }^{3}$}

\subsubsection{The market reaction}

We use two measures to capture the market reaction around the date of earnings announcements. Following DeFond et al. (2007) and Landsman et al. (2012), we use the abnormal returns volatility (AVAR). We compute abnormal returns as the predictions errors from the market model estimated over 220 daily returns $(t=-120$ to $t=-10$ and $t=+10$ to $t=+120)$ around the event date:

$$
\mathrm{AR}_{\mathrm{it}}=R_{i t}-\left(\propto_{i}+\beta_{i} R_{m t}\right)
$$

where $R_{i t}$ is the effective stock market return of firm i on event day $\mathrm{t}, R_{m t}$ is the market index return on the same day, and $\propto_{i}$ and $\beta_{i}$ are the market model's estimates for firm i obtained during the estimation period. Since we study a European sample, we use the Euro Stoxx 50 as the market index, which is composed of the 50 largest firms in terms of market capitalization in the Eurozone.

AVAR is the natural log of the ratio of the mean squared abnormal returns during the event window $(t=0$ to $t=+1)$, with the event occurring at day 0 , divided by the abnormal returns variance during the estimation window. We use the natural log to avoid biases due to the skewness of the ratio. ${ }^{4}$

$$
\operatorname{AVAR}_{\mathrm{i}}=\ln \left(\frac{\frac{1}{N} \sum_{1}^{N} A R_{i}^{2}}{\sigma_{i, A R_{e s t}}^{2}}\right)
$$

\footnotetext{
3 The definitions of all variables (used for the main analysis and the robustness tests) are summarized in Appendix 1.

${ }^{4}$ In all regressions, the market reaction variables as well as the earnings surprises are winsorized at their respective 1 st and 99 th percentiles to mitigate the effect of outliers. Finally, standard errors are adjusted for heteroskedasticity and firm-level clustering, consistent with Petersen (2009).
} 
Panel A in table 3 shows that the mean (median) value of AVAR is equal to 0.59 (0.80) for the full sample. Panel B and C highlight that AVAR is higher in countries with strong institutions (mean equal to 0.65) compared to countries with weak institutions (mean equal to 0.53).

Our second measure of market reaction is the abnormal trading volume (AVOL). Consistent with DeFond et al. (2007) and Landsman et al. (2012), we measure the abnormal trading volume (AVOL) as the average trading volume over the event period $(t=-1$ to $t=+1)$ divided by the average trading volume over the 100 -days estimation window $(t=-60$ to $t=-10$ and $t=+10$ to $t=+60)$ :

$$
\operatorname{AVOL}_{\mathrm{i}}=\frac{\frac{1}{T} \sum_{t=-1}^{1} V_{i t}}{\frac{1}{N} \sum_{n=1}^{100} V_{i n}}
$$

where $V_{i t}$ is the number of shares of firm i traded on day t. If invetors trade more stocks than usual during the event period window, then AVOL is larger than one. For the full sample, which is reduced to 6'732 observations for AVOL due to missing data, the mean (median) value is equal to 2.10 (1.60). For countries with strong institutions, AVOL is also larger (mean equal to 2.27) compared to countries with weak institutions (mean equal to 1.92).

\section{[ INSERT TABLE 3 ]}

\subsubsection{The independent variables of interest}

\section{The institutional context}

All firms included in our sample use IFRS. However, it is well-known that some differences remain in the way these standards are applied and enforced across countries (Ball, 2006; Brown, 2011; Christensen, Hail and Leuz, 2013). These differences have a significant impact on the credibility of financial information disclosed to investors. In 
addition, we also know that it is more likely that external auditors do not fulfil their role in the same way in various contexts, because they face different litigation or reputational risks (Choi and Wong, 2007; Choi et al., 2008; Francis and Wang, 2008; DeFond and Zhang, 2014).

Several proxies have been developed in the literature to capture variations in institutional settings, generally focusing on shareholders' legal protection and on the legal system (e.g. De Silanes et al., 1998; Kaufman et al., 2009; Leuz, 2010; Brown et al., 2014). We start with the index recently developed by Brown et al. (2014), composed of a measure of external auditors' working environment and accounting standards enforcement. This index has a high explanatory power for financial transparency measures and for differences in earnings management across countries, when compared to other measures (e.g. Brooks et al., 2017).

Brown et al. (2014) build their audit index as the sum of nine sub-groups with different weights (the maximum score is in parenthesis): license (2), additional requirements (2), professional development (2), quality assurance program (2), oversight body (4), sanctions (4), rotations (4), level of audit fees (6), and level of litigation risk (6). The enforcement index is computed as the sum of six sub-groups with different weights: regulatory body in place (2), sets standards (2), reviews financial statements (4), reports surveillance programs (4), has taken enforcement action (6), and the level of resourcing based on the number of staff employed by the regulator (6). We use the most recent scores (2008) proposed by these authors.

Panel A in appendix B describes the total scores by country as well as the enforcement and audit scores for the Brown et al. (2014) index. We consider the countries 
that have a total score equal to or above the sample median score as having strong institutions and the countries that have a total score equal or below the median score as having weak institutions. There are large differences in Western Europe. The UK has the largest score (54), which is as twice as important as the lowest score obtained by Austria (27). To control for the potential limitations of the Brown et al. (2014) index, we also adopt two indices from the World Bank Group in an additional analysis (section 4.3).

\section{The independence of the audit committee}

An independent audit committee is composed of members that are independent from management and from the firm in general. More precisely, members are supposed to be independent when there is no personal relationship (i.e. the member should not be from the same family or a friend of the CEO), no employment relationship (i.e. the member should not be a current or a former employee of the company), and no business relationship (i.e. the member should not be a consultant, an advisor, a large client, or a supplier). To identify the degree of independence of the audit committee, we use the Boardex database that includes the name of the members and a dummy variable for independent members. We acknowledge that the extraction of these variables is a limitation of our study, as all companies in all countries do not necessarily use the same criteria to define independent members.

For each committee, we compute the percentage of independent members as the number of independent members of a given audit committee divided by the size of this committee. Table 3 shows that, on average, $70 \%$ of the members are independent (median equal to $100 \%$ ), but this figure varies with the institutional context. Indeed, $78 \%$ of the members are independent on average (median equal to 100\%) in countries with strong 
institutions, while only $61 \%$ of the members are independent on average (median equal to $67 \%)$ in countries with weak institutions. These differences may be due to stricter regulation regarding the composition of audit committees in countries with stronger institutions compared to the European regulation, or to the presence of more independent members sitting on the audit committee on a voluntary basis in countries with stronger institutions.

\section{The levels of independence}

Since the European regulation changed recently, but is still different from the US regulation (SOX), we also consider various levels of audit committee's independence. To capture the relevance of the new European regulation, which requires public-interest entities to have at least $50 \%$ of independent members sitting on the audit committee (AC), we create three variables. LESS_THAN_50 is a dummy variable taking the value of 1 if less than $50 \%$ of the members sitting on the $\mathrm{AC}$ are independent and 0 otherwise. FROM_50_TO_99 is a dummy variable taking the value of 1 if at least 50\% of the members sitting on the $\mathrm{AC}$ are independent but the $\mathrm{AC}$ is not fully independent, and 0 otherwise. Finally, FULLY_INDEP is a dummy variable taking the value of 1 if $100 \%$ of independent members are sitting on the audit committee, and 0 otherwise.

In table 4 , we show the distribution of the percentage of independent members (IM). We find that $24 \%$ of our sample has less than $50 \%$ of IM, $25 \%$ of our sample has between $50 \%$ and $99 \%$ of IM, and $51 \%$ has fully independent audit committees. ${ }^{6}$ There are, however, some important differences between firms in the weak institutional environment (IE) and those in the strong institutional environment (IE). For the weak IE,

\footnotetext{
${ }^{6}$ We note that many companies (included in "other cases" in table 4) do not have independent members sitting on the audit committee.
} 
about one third of the AC is included in each subsample (respectively, 30\%, 36\% and 34\%), whereas for the strong IE, a large majority of AC is fully independent (67\%) and only $17 \%$ of the AC have less than $50 \%$ of IM.

Regarding the distribution by number of members sitting on the $\mathrm{AC}$, we show that the percentage of IM depends on the size of the audit committee. For instance, when we compare AC having 2 members with AC having 6 members, we highlight that the percentage of IM in the first subsample (less than 50\%) is greater for larger AC (55\% with 6 members) than for smaller AC (21\% with 2 members). Similar differences appear for the last subsample (fully independent AC). For instance, we find $18 \%$ of IM for larger AC (6 members) compared to $61 \%$ of IM for smaller AC (2 members). Finally, there are important differences between the two institutional environments. For instance, when 6 members are sitting on fully independent $\mathrm{AC}$, the percentages are respectively equal to $7 \%$ and $76 \%$ in weak IE and strong IE. Since important differences exist, we provide some specific tests in section 4.1 to understand if and how such differences affect our results.

Finally, in appendix $\mathrm{C}$, we describe the evolution of the percentage of independent members for the period 2006-2014 under study. The average percentage is pretty stable for the full sample (around 70\%), but the percentage in weak IE is increasing (from 58\% to $64 \%$ ) while the percentage in strong IE in decreasing (from $87 \%$ to $76 \%$ ). Overall, our descriptive statistics support the idea that there is some dispersion in the independence of $\mathrm{AC}$ in European firms.

\section{[ INSERT TABLE 4 ]}

\subsubsection{The control variables}


In our models, we control for numerous factors that may impact the market reaction to earnings announcements. ${ }^{7}$

\section{Earnings surprise}

Following DeFond et al. (2001) and Francis et al. (2002), we measure the earnings surprise to earnings announcements with the standardized unanticipated earnings (SUE) ${ }^{8}$, which is available on IBES. SUE is equal to the actual EPS minus the expected mean EPS, divided by the standard deviation of analysts' estimates. The descriptive statistics in table 3 highlight that the mean (median) SUE is $0.25(0.00)$ for the whole sample, while it amounts to $0.44(0.00)$ in countries with strong institutions and to $0.05(0.00)$ in countries with weak institutions.

\section{Size}

It is well-documented that less information is conveyed in earnings announcements for larger firms (e.g. Atiase, 1985). We proxy the size of the announcing firm (SIZE) with the natural logarithm of total assets (in euros). In the full sample, the average (median) size of announcing firms is 13.49 (13.52), but companies in countries with weak institutions are larger than those in countries with strong institutions.

\section{Leverage}

In line with Landsman et al. (2012) and Pevzner et al. (2015), we control for the leverage of the firm, which might also affect the market reaction. Our variable LEVERAGE is computed as the ratio of long term debt divided by total assets. For the full sample, the

\footnotetext{
${ }^{7}$ We also control for industry- and year-fixed effects. However, we do not control for country fixed effects as we control for country-level institutional factors with the Brown et al. index. In untabulated tables, we find that the results hold when we add country fixed effects.

${ }^{8}$ In an unreported robustness test, we replace our earnings surprise metrics, SUE, by an alternative measure of earnings surprise that we call EPS_surprise. We compute this variable as the difference between the actual earnings and the median analysts' forecast available on Datastream, divided by the median analysts' forecast. Our results do not change with this alternative metrics.
} 
mean (median) leverage is 21\% (20\%), but the leverage is higher in countries with weak institutions.

\section{Growth opportunities}

Firms with more growth opportunities, and thus with greater financing needs, might have stronger incentives to disclose credible accounting information (Bonetti et al., 2016). To control for growth opportunities (MTB), we use the market-to-book ratio, which is equal to the market value of equity divided by the book value of equity. In our full sample, the mean (median) market-to-book is 2.45 (1.72), but this ratio is larger in countries with strong institutions.

\section{Disclosure of a loss}

We control for the disclosure of a loss because firms reporting a loss have less informative earnings (Hayn, 1995). For the disclosure of a loss, we use a dummy variable (D_LOSS) that takes the value of one if the EPS is negative, and zero otherwise. In our sample, losses are observed in $15 \%$ of the sample, and there are no differences between the two institutional contexts.

\section{External auditors (Big Four)}

To take into account earnings management in our analysis, we include the variable BIG_4 which takes the value of 1 if the announcing firm's auditor is a Big Four, and 0 otherwise. Academic literature shows that there is less earnings management in firms audited by a Big Four (Healy et al., 1999; Choi and Wong, 2007; Francis et al., 2013; DeFond and Zhang, 2014). In our sample, $78 \%$ of the announcing firms use a Big Four as external auditor. Again, there are only small differences between the two institutional contexts.

\section{Abnormal accruals}


Our second variable measuring earnings management is the level of abnormal accruals (ABN_ACC). We follow Francis et al. (2013) to compute the abnormal accruals. In our sample, the average (median) abnormal accruals is nil by construction as they are the error term of a total accruals model.

\section{Reporting lag}

A longer reporting lag may lead to more earnings information supplied before the announcement date and decreases the market reaction (Chambers and Penman, 1984). For the reporting lag (REPORT_LAG), we compute the number of days between fiscal year end and the announcement date for a given year. The mean (median) reporting lag is 67 (63) days, and no large differences appear between the two institutional contexts.

\section{Cross-listing}

Cross-listed firms in the US face more constraints, have greater coverage by analysts and increased forecast accuracy, and thus evolve in a better information environment (Lang et al., 2003). Cross-listing (CROSS_LIST) is a dummy variable equal to 1 if the announcing firm is listed in the US and 0 otherwise. In our sample, $4 \%$ of the announcements are made by firms listed in the US, and similar percentages are obtained in the two institutional contexts.

\section{Experience of the audit committee}

The literature on audit committees' composition generally shows that expertise is a key factor explaining the effectiveness of audit committees, which in turn may affect accounting quality (e.g. Bédard and Gendron, 2010; DeFond and Zhang, 2014). Given that we cannot assess the expertise of the members in the Boardex database, we refer to the experience of the members on the board, which is a raw proxy for expertise. Our measure 
of the experience (EXPERIENCE) is equal to the median number of years spent on the board by the members sitting on the audit committee. In our sample, the average (median) experience is equal to 5.4 (4.7) years. In countries with weak institutions, audit committee members are more experienced (about 6 years on average versus 4.8 years in countries with strong institutions).

\section{Size of the audit committee}

Some studies show that the size of the audit committee might influence earnings management, which ultimately might impact the market reaction to earnings announcements (e.g. Bédard and Gendron, 2010). Thus, we also control for the size of the audit committee. Our variable AC_SIZE is equal to the number of members sitting on this committee. In the full sample, the average (median) number of members sitting on the audit committee is 3.3 (3). We do not observe large differences between the two institutional contexts.

\section{Size of the board}

Finally, following the same rationale as the previous variable (size of the audit committee), we also control for the size of the board (BOARD_SIZE) with a variable that is equal to the number of directors sitting on the board. In our sample, the average (median) number of directors sitting on the board is equal to 9.4 (8). In countries with strong institutions, the size of the board is smaller ( 7.4 on average) than in countries with weak institutions (11.4 on average).

\section{Main results}

\subsection{Results from the analysis of correlations}


We start with a short analysis of the correlations between our variables. The matrix of correlations in Appendix D shows that the two measures of market reaction (AVAR and AVOL) are significantly correlated, which means that they capture the same phenomenon, but not exactly in the same way, since the correlation is not close to 1 . We also find that our two measures of market reaction are positively and significantly associated to the independence of the audit committee. Furthermore, we find a similar result for the strength of the institutional context, which means that the market reaction is stronger when institutions favour the credibility of earnings. Finally, our two variables of interest are positively and significantly associated: audit committees are more independent in countries with strong institutions. Overall, as expected, these first results seem to indicate that the market seems to care about the credibility of earnings, since there is a greater market reaction when institutions are stronger and when more independent members are sitting on the committee audit.

We also highlight that audit committees are more independent in firms that are larger (SIZE), cross-listed (CROSS_LIST), profitable (D_LOSS), and audited by a Big 4 (BIG_4). In addition, firms with more independent members sitting on the audit committee announce larger earnings surprises (SUE), have less experienced members (EXPERIENCE), and have smaller boards (BOARD_SIZE) and audit committees (AC_SIZE). Second, in countries with strong institutions, the firms are smaller, less levered and disclose losses more frequently (D_LOSS). Moreover, in these countries, firms announce larger surprises (SUE), have larger growth opportunities (MTB), less experienced members (EXPERIENCE), and smaller boards (BOARD_SIZE) and audit committees 
(AC_SIZE). Finally, firms in countries with strong institutions hire less often a Big 4 (BIG_4). The multivariate analysis provides more relevant results.

\subsection{Results from the regressions}

\subsubsection{Results for the total index}

Table 5 describes the results for models 2 and 3 on the full sample. The dependent variables measuring the market reaction to earnings announcements are the abnormal returns variance (AVAR) in columns 1 and 2, and the abnormal trading volumes (AVOL) in columns 3 and 4 . For the two measures of market reactions, we show that the independence of the audit committee (INDEP_AC) is positively and significantly associated with the market reaction to earnings announcements. It supports the fact that investors react more to disclosures made by firms with more independent audit committees, because the latter improves the credibility of earnings. The Brown et al. (2014) total index (INSTIT_CONTEXT) is also positively related to investors' reaction, meaning that earnings announcements are more credible in strong institutional environments. Moreover, in model 2 (columns 2 and 4), the interaction term (INDEP_AC*INSTIT_CONTEXT) indicates that investors react less to announcements made by firms with more independent audit committees in countries with strong institutions. Thus, the independence of the audit committee acts as a substitute for weak institutional context in making financial disclosures more credible.

Concerning the control variables, we find that investors react less to negative earnings announcements (D_LOSS), which is line with the results obtained by DeFond et al. (2007). The reaction is also lower for firms with more debt (LEVERAGE). Consistent with Pevzner et al. (2015), the market reacts more for larger firms (SIZE) with AVAR, but 
less for larger firms with AVOL. Finally, the market reacts more for cross-listed firms (CROSS_LIST) and firms with smaller audit committees (AC_SIZE), but only with AVOL. These results support that AVOL and AVAR, although both used jointly as an information content measure in the literature, do not exactly measure the same thing (Bailey et al., 2006). The r-squared of our models is low $(4 \%)^{9}$ but, overall, the $\mathrm{F}$ tests show that our models perform well.

\section{[ INSERT TABLE 5 ]}

Table 6 shows the results for AVAR and AVOL with model 1 for the full sample (columns 1 and 2) and for the two sub-samples composed of firms in countries with strong institutions (columns 3 and 4) and weak institutions (columns 5 and 6). The percentage of independent members in the audit committee (INDEP_AC) is positively and significantly related to the market reaction (AVAR and AVOL) in countries with weak institutions (columns 5 and 6), but this is not the case in countries with strong institutions (columns 3 and 4). These results support the idea that the audit committee's independence acts as a substitute in a weak institutional context. In other words, if investors consider that the institutional context does not favor the credibility of earnings, then they will react more strongly to earnings announcements when an independent audit committee acts as a mechanism making earnings more credible. In contrast, if the institutional context leads to the disclosure of more credible earnings, then investors seem to care less about the independence of the audit committee. Similar substitution effects have been found by Choi

\footnotetext{
${ }^{9}$ In similar studies, DeFond et al. (2007) and Bonetti et al. (2016) also present low r-squared.
} 
and Wong (2007) for external auditors, which play a more important role in countries with weak institutions compared to countries with strong ones.

\section{[ INSERT TABLE 6 ]}

Various control variables are also significant. The sign of the coefficients on D_LOSS is negative and significant when institutions are strong. The sign of the coefficients on LEVERAGE is negative in countries with weak institutions. Finally, the sign on SIZE is positive when the market reaction is proxied by AVAR in weak institutions, and negative with AVOL in both contexts.

\subsubsection{Results for the two sub-indices}

We further investigate whether the substitution effect that we observe is related to the quality of the audit working environment or the level of enforcement of accounting standards, which are both components of the Brown et al. (2014) total index.

In table 7 , we run models 1 and 2 with the Brown et al. (2014) sub-indices as continuous variables. In columns 1 to 4 , we analyse the role of the audit working environment index (AUDIT_INDEX) in explaining the market reaction to earnings announcements (measured with AVAR and AVOL). We show that the percentage of independent members in the audit committee (INDEP_AC) is positively related to investors' reaction with AVAR. In addition, the audit index (AUDIT_INDEX) is also positively and significantly associated to the market reaction measured by AVAR. When we account for the interaction term (INDEP_AC*AUDIT_INDEX), it appears that the market reaction measured by AVAR is smaller for firms with more independent audit committees in countries with strong audit indices. The audit index has only a limited impact on AVOL. 
In columns 5 to 8 of table 7 , we investigate the role of the enforcement index (ENFORCE_INDEX). In model 3 (columns 6 and 8), the enforcement index is positively associated with the market reaction (AVAR and AVOL), but the interaction term (INDEP_AC*ENFORCE_INDEX) affects negatively and significantly the market reaction. Overall, our main result concerning the substitution effect is not driven by any sub-index for AVAR. However, the substitution effect might be driven by the enforcement sub-index with AVOL.

\section{[ INSERT TABLE 7 ]}

In a final step concerning the Brown et al. (2014) sub-indices, we split our sample based on the median of the audit index (columns 1 to 4 ), and based on the median of the enforcement index (columns 5 to 8 ). The results for model 3 in table 8 are consistent with a substitution effect between the audit environment and the independence of the audit committee when the audit index is weak. However, we do not find such an effect when the audit environment is strong. Similar results are found between the enforcement environment (ENFORCE_INDEX) and the independence of the audit committee. Overall, the results in table 8 highlight that our previous results are not different for the two subindices (the audit environment or the enforcement environment).

\section{[ INSERT TABLE 8 ]}

\section{Additional results}

In this section, we analyse how the various levels of independence of $\mathrm{AC}$ and the size of the $\mathrm{AC}$ affect the market reaction. We also control that our main results still hold when we use an alternative measure of the market reaction to earnings announcements, or an 
alternative measure of the institutional context, but also when we exclude the UK (which represents a large part of the sample). Finally, we control for the potential endogeneity of the audit committee's composition.

\subsection{The levels of independence and the number of members on the audit committee}

Since the percentage of independent members varies with the number of members sitting on the $\mathrm{AC}$, we provide an additional analysis for four sub-samples, depending on the AC size (2, 3, 4 or 5 members). Overall, table 9 shows that the size of the audit committee does not affect our results. For ACs composed of 2, 3 or 5 members, the market reaction to earnings announcements is stronger when the $\mathrm{AC}$ has between $50 \%$ and $99 \%$ of independent members (FROM_50_TO_99), as compared to less than 50\% independent members. For ACs composed of 2, 3, 4 or 5 members, the market reaction to earnings announcements is also significantly stronger when the $\mathrm{AC}$ is fully independent (FULLY_INDEP), as compared to less than 50\% independent members.

Furthermore, the association between FULLY_INDEP and the market reaction to earnings announcements is significant in weak IE (except for $\mathrm{AC}$ size $=4$ ) but not in strong IE. When the AC is not fully independent (FROM_50_TO_99), the differences in market reaction between weak and strong IE are less pronounced. These results suggest that, in weak institutional settings, the relationship between $\mathrm{AC}$ independence and the market reaction to earnings announcements is largely driven by ACs that are $100 \%$ independent.

We complete the previous results by showing, in an untabulated table, that the size of the $\mathrm{AC}$ does not affect the market reaction for fully independent $\mathrm{AC}$. Indeed, the 
coefficients of the four dummy variable (AC_size=2, AC_size=3, AC_size=4 and AC_size=5) are not significant for the subsample of fully independent AC.

\section{[ INSERT TABLE 9 ]}

\subsection{Alternative measure of market reaction}

We also use an alternative measure of market reaction, namely the cumulative abnormal returns (CAR). In a first step, we compute abnormal returns as the predictions errors from the market model estimated over 220 daily returns around the event date:

$$
\mathrm{AR}_{\mathrm{it}}=R_{i t}-\left(\propto_{i}+\beta_{i} R_{m t}\right)
$$

where $R_{i t}$ is the effective stock market return of firm i on event day t; $R_{m t}$ is the market index return on the same day; and $\alpha_{i}$ and $\beta_{i}$ are the market model's estimates for firm $\mathrm{i}$ obtained during the estimation period $(t=-120$ to $t=-10$ and $t=+10$ to $t=+120)$. Since our sample is composed of European firms, we use the Euro Stoxx 50 as the market index, which is composed of the 50 largest firms in terms of market capitalization in the Eurozone. In a second step, we sum the abnormal returns of the event day and the day after $(\mathrm{t}=0$ to $\mathrm{t}=+1)$ to obtain the cumulative abnormal returns:

$$
\mathrm{CAR}_{\mathrm{i}}=\sum_{t=0}^{1} A R_{i t}
$$

The (untabulated) findings are generally consistent with those found with AVAR and AVOL. Indeed, there is a positive and significant association between the cumulative abnormal returns (CAR) and both variables of interest: the percentage of independent audit committee members (INDEP_AC) and the strength of the institutional context (INSTIT_CONTEXT). When we test model 1 for strong and weak environments 
(INSTIT_CONTEXT, AUDIT_INDEX and ENFORCE_INDEX), the results support the idea of a substitution effect. With the Brown et al. (2014) total index, but also with the World Bank Group overall index, the coefficient on INDEP_AC is positive and significant in countries with weak institutions, but not in countries with strong ones. Similar results are obtained for the two sub-indices (AUDIT_INDEX and ENFORCE_INDEX).

\subsection{Alternative proxy for the institutional context}

We also use an alternative proxy (Worldwide Governance Indicators) from the World Bank Group to control for the potential limitations of the Brown et al. (2014) index, especially the fact that the institutional contexts have changed between 2006 and 2014. The World Bank Group defines it as a tool "useful for broad cross-country comparisons and for evaluating broad trends over time", and it is composed of six items: Voice and Accountability; Political Stability and Absence of Violence; Government Effectiveness; Regulatory Quality; Rule of Law; and Control of Corruption. The World Bank website ${ }^{10}$ reports aggregate and individual governance indicators for over 200 countries and territories over the period 1996-2016, for these six dimensions of governance. These data were already used in empirical research by Bonetti et al. (2016).

Since we are interested in institutional factors that may curb earnings management and therefore increase earnings credibility, we argue that not all items are relevant for our study. We only use two items: Rule of Law and Regulatory Quality. Rule of Law is "reflecting perceptions of the extent to which agents have confidence in and abide by the rules of society, and in particular the quality of contract enforcement, property rights, the police, and the courts, as well as the likelihood of crime and violence." Regulatory Quality

\footnotetext{
${ }^{10}$ http://info.worldbank.org/governance/wgi/\#home
} 
is "reflecting perceptions of the ability of the government to formulate and implement sound policies and regulations that permit and promote private sector development." We consider that there is no (direct) link between the other items and financial reporting quality. ${ }^{11}$ We also construct an overall index, which is the average of the two previous items (Rule of Law and Regulatory quality). Panel B in appendix B presents the scores for the 15 countries.

The results in table 10 show that the variable INDEP_AC is positive and significant in nine models out of twelve. The three institutional proxies (from the World Bank Group) are also positive and significant. The interaction term is negative and significant for AVAR with the three indices. However, the interaction term is not significant for AVOL. Thus, with this alternative index, we confirm that the market reaction (AVAR) is stronger in countries with better institutions in place to protect shareholders from managers' misbehaviour (i.e. earnings management in our case). However, the market reaction measured with the abnormal returns variance is still lower for earnings announcements in firms in which more independent members are sitting on the audit committee and located in countries with stronger institutions (substitution effect).

\section{[ INSERT TABLE 10 ]}

\footnotetext{
11 "Voice and accountability" captures perceptions of the extent to which a country's citizens are able to participate in selecting their government, as well as freedom of expression, freedom of association, and a free media. "Political Stability and Absence of Violence" measures perceptions of the likelihood of political instability and/or politically motivated violence, including terrorism. "Government effectiveness" captures perceptions of the quality of public services, the quality of the civil service and the degree of its independence from political pressures, the quality of policy formulation and implementation, and the credibility of the government's commitment to such policies. "Control of corruption" captures perceptions of the extent to which public power is exercised for private gain, including both petty and grand forms of corruption, as well as "capture" of the state by elites and private interests.
} 
The results presented in Table 11 confirm the substitution effect. In this separate analysis of the two sub-samples of strong institutions and weak institutions, we show that the presence of more independent members sitting on the AC does not affect the market reaction (AVAR and AVOL) in the first sub-group. In countries with weak institutions, however, the variable INDEP_AC is positive and significant at the $1 \%$ level for the variable AVAR. Thus, having more independent members is associated with larger market reactions in European countries with weak institutions. Overall, we conclude that the results obtained with the Brown et al. (2014) and the World Bank Group indices lead to the same conclusion.

\section{[ INSERT TABLE 11 ]}

\subsection{Tests without UK}

As the UK represents $43.1 \%$ of our sample, we also test our models without the UK to control for the existence of a "UK-effect". Since the Brown et al. (2014) total index and the World Bank Group overall index rank the UK among countries with a strong institutional setting, we only run the tests for the full sample without UK and for the subsample of countries with strong institutions.

For the full sample without UK, our (untabulated) results are similar to those with the UK. With the two indices (Brown et al., 2014; World Bank Group), we find a positive and significant impact of the independence of the audit committee on the market reaction. With model 1 and model 2, INDEP_AC is always positive and significant. In model 2, the interaction term (INDEP_AC*INSTIT_CONTEXT) is still negative. For the sub-sample of countries with strong institutions (without UK), we show that the coefficients on 
INDEP_AC are still non-significant. Overall, our results are unchanged when we exclude the UK. ${ }^{12}$

\subsection{The endogeneity of the audit committee's independence}

Finally, one could argue that the composition of the audit committee is not random (endogeneity). In that case, an omitted variable correlated with the percentage of independent members on the audit committee would limit the relevance of our findings about the significant relationship between the independence of the audit committee and the information content of earnings announcements in various institutional contexts. To mitigate the concerns about a potential omitted variable that would make our relationships spurious, we develop a two-step procedure using a 2SLS regression. The instrumental variable we use is the ownership structure, which is proxied by the percentage of closely held shares (OWNERSHIP) obtained on Datastream. This instrument is negatively and significantly correlated with INDEP_AC (i.e. higher ownership concentration leads to a lower percentage of independent members sitting on the audit committees), but is not correlated with our market reaction measures (AVAR and AVOL) and with the error term of the regression.

Table 12 reports the results of our 2SLS regressions for the full sample as well as for the strong and the weak institutions subsamples. The first-stage regressions are reported in column $1,3,5,7,9$ and 11 . The second-stage regressions are reported in columns 2, 4, 6, 8, 10 and 12. In line with our OLS results, the instrumented version of INDEP_AC is positively and significantly related to the market reaction measured with

\footnotetext{
${ }^{12}$ Since many countries have a score close to the median, we also consider this issue by using only the five countries with the lowest indices and the five countries with the largest indices in an untabulated test. Our results do not change.
} 
AVOL and AVAR (column 2 and 4) for the full sample. In the weak institutional environment, the instrumented version of INDEP_AC is positively and statistically related to both market reaction proxies, as expected. In countries with strong institutions, the instrumented version of INDEP_AC is not associated to AVOL, but is related to AVAR at

the 5\% threshold. Overall, these results support that after correcting for the endogeneity of the audit committee's independence, the relation between INDEP_AC and the market reaction still holds, and the substitution hypothesis remains valid with AVOL.

\section{[ INSERT TABLE 12 ]}

\section{Conclusion}

This paper analyses the role played by independent audit committees in credibilizing earnings announcements in different institutional settings and, therefore, in affecting the reaction of financial markets. In a large sample of public companies in Western Europe for the period 2006-2014, we find that the independence of audit committees (measured with the percentage of independent members sitting on the audit committee) plays a key role in explaining the market reaction to earnings announcements. More importantly, when differentiating between firms in countries with strong or weak institutions (based on the Brown et al. (2014) or the World Bank Group indices), we find that this relation only holds in countries with weak institutions (i.e. in countries where institutions do not favor greater credibility of earnings). This finding supports the idea that the independence of audit committees acts as a substitute for weak institutions to improve the credibility of earnings announcements. In addition, we show that fully independent audit committees especially affect the market's reaction in countries with weak institutional settings. However, we acknowledge that relying on the companies' classification of independence is a limitation 
of our study. It is likely that there are some errors in this classification. In particular, some firms may classify some non-independent members as independent members. Thus, in future studies, it would be interesting to see if our results are affected by other measures of independence.

Even with this limitation, we argue that our results are particularly interesting for European regulators that have recently issued a new directive regarding the composition of audit committees. Indeed, since 2016, public firms are required to appoint at least 50\% of independent members instead of (at least) one member. As highlighted in this paper, fully independent audit committees have a greater impact on the market's reaction of earnings announcements in countries with weak institutions. Thus, we argue that the actual regulation is not going far enough. Since it is possible for each European country to introduce stricter rules than those proposed by the European Commission, we suggest that the regulators in countries with weak institutions impose fully independent audit committees (i.e. $100 \%$ of independent members).

More work is needed on this topic to help regulators and practitioners improve the effectiveness of European audit committees. In particular, we don't know yet how some personal characteristics of the (independent or not) members affect their behavior and, ultimately, the effectiveness of the $\mathrm{AC}$ and the credibility of earnings. For instance, what is the impact of the tenure of the members, or their financial expertise? Moreover, what are the consequences on the effectiveness of the boards of directors when more independent members must sit on the audit committee? Several papers using US data have already tackled these aspects (Bédard and Gendron, 2010; DeFond and Zhang, 2014). It would be interesting to understand which rules and practices can be transposed to the 
various European institutional contexts to improve the effectiveness of the audit committee. 


\section{References}

Abbott, L. J., Park, Y., and Parker, S. (2000). The effects of audit committee activity and independence on corporate fraud. Managerial Finance, 26 (11), 55-68.

André, P., Broye, G., Pong, C., and Schatt, A. (2016). Are joint audits associated with higher audit fees? European Accounting Review, 25 (2), 245-274.

Atiase, R. K. (1985). Predisclosure information, firm capitalization, and security price behavior around earnings announcements. Journal of Accounting Research, Spring, 2136.

Bailey, W., Karolyi, G. A., and Salva, C. (2006). The economic consequences of increased disclosure: Evidence from international cross-listings. Journal of Financial Economics, 81 (1), 175-213.

Ball, R., Kothari, S. P., and Robin, A. (2000). The effect of international institutional factors on properties of accounting earnings. Journal of Accounting and Economics, 29 (1), 1-51.

Ball, R. (2006). International Financial Reporting Standards (IFRS): pros and cons for investors. Accounting and Business Research, 36 (sup. 1), 5-27.

Beasley, M. S., Carcello, J. V., Hermanson, D. R., and Lapides, P. D. (2000). Fraudulent financial reporting: Consideration of industry traits and corporate governance mechanisms. Accounting Horizons, 14 (4), 441-454.

Beaver, W. H. (1968). The information content of annual earnings announcements. Journal of Accounting Research, 6, 67-92.

Becher, D. A., and Frye, M. B. (2011). Does regulation substitute or complement governance? Journal of Banking and Finance, 35 (3), 736-751.

Bédard, J., Chtourou, S. M., and Courteau, L. (2004). The effect of audit committee expertise, independence, and activity on aggressive earnings management. Auditing: A Journal of Practice and Theory, 23 (2), 13-35.

Bédard, J., and Gendron, Y. (2010). Strengthening the Financial Reporting System: Can Audit Committees Deliver? International Journal of Auditing, 14 (2), 174-210.

Bonetti, P., Pabonetti, A., and Magnan, M. (2016). The influence of country-and firm-level governance on financial reporting quality: Revisiting the evidence. Journal of Business, Finance and Accounting. Forthcoming.

Bronson, S.N.. Carcello, J.V.. Hollingsworth, C.W., and Neal, T.L. (2009) Are fully independent audit committees really necessary? Journal of Accounting \& Public Policy, 28 (4), 265-280.

Brooks, L., Cheng, C. S. A., Johnston, J. A., and Reichelt, K. J. (2017). Estimates of Optimal Audit Firm Tenure Across Different Legal Regimes. Journal of Accounting, Auditing \& Finance, 32 (1), 3-39.

Brown, P. (2011). International Financial Reporting Standards: what are the benefits? Accounting and Business Research, 41 (3), 269-285. 
Brown, P., Preiato, J., and Tarca, A. (2014). Measuring country differences in enforcement of accounting standards: An audit and enforcement proxy. Journal of Business Finance \& Accounting, 41 (1-2), 1-52.

Carcello, J. V., and Neal, T. L. (2003). Audit committee independence and disclosure: Choice for financially distressed firms. Corporate Governance: An International Review, 11 (4), 289-299.

Chambers, A. E., and Penman, S. H. (1984). Timeliness of reporting and the stock price reaction to earnings announcements. Journal of Accounting Research, 22 (1), 21-47.

Choi, J. H., Kim, J. B., Liu, X., and Simunic, D. A. (2008). Audit pricing, legal liability regimes, and big 4 premiums: Theory and cross-country evidence. Contemporary Accounting Research, 25 (1), 55-99.

Choi, J. H., and Wong, T. J. (2007). Auditors' governance functions and legal environments: An international investigation. Contemporary Accounting Research, 24 (1), 13-46.

Christensen, H. B., Hail, L., and Leuz, C. (2013). Mandatory IFRS reporting and changes in enforcement. Journal of Accounting and Economics, 56 (2), 147-177.

Dechow, P., Ge, W., and Schrand, C. (2010). Understanding earnings quality: A review of the proxies, their determinants and their consequences. Journal of Accounting and Economics, 50 (2), 344-401.

DeFond, M. L., Hann, R. N., and Xuesong H. (2005). Does the Market Value Financial Expertise on Audit Committees of Boards of Directors? Journal of Accounting Research. 43 (2), 153-193.

DeFond, M. L., and Park, C. W. (2001). The reversal of abnormal accruals and the market valuation of earnings surprises. The Accounting Review, 76 (3), 375-404.

DeFond, M. L, Hung, M., and Trezevant, R. (2007). Investor protection and the information content of annual earnings announcements: International evidence. Journal of Accounting and Economics, 43 (1), 37-67.

DeFond, M. L., and Zhang, J. (2014), A review of archival auditing research. Journal of Accounting and Economics. 58 (2), 275-326.

De Silanes, F. L., La Porta, R., Shleifer, A., and Vishny, R. (1998). Law and finance. Journal of Political Economy, 106 (6), 1113-1155.

Directive 2006/43/EC of the European Parliament and of the Council of 17 May 2006 on statutory audits of annual accounts and consolidated accounts, amending Council Directives 78/660/EEC and 83/349/EEC and repealing Council Directive 84/253/EEC.

Directive 2014/56/UE du Parlement européen et du Conseil du 16 avril 2014 modifiant la directive 2006/43/CE concernant les contrôles légaux des comptes annuels et des comptes consolidés Texte présentant de l'intérêt pour l'EEE.

Francis, J. R., Michas, P. N., and Seavey, S. E. (2013). Does audit market concentration harm the quality of audited earnings? Evidence from audit markets in 42 countries. Contemporary Accounting Research, 30 (1), 325-355. 
Francis, J., Schipper, K., and Vincent, L. (2002). Expanded disclosures and the increased usefulness of earnings announcements. The Accounting Review, 77 (3), 515-546.

Francis, J. R., and Wang, D. (2008). The joint effect of investor protection and Big 4 audits on earnings quality around the world. Contemporary Accounting Research, 25 (1), 157191.

Hayn, C. (1995). The information content of losses. Journal of Accounting and Economics, 20 (2), 125-153.

Healy, P. M., and Wahlen, J. M. (1999). A review of the earnings management literature and its implications for standard setting. Accounting Horizons, 13 (4), 365-383.

Klein, A. (2002). Audit committee, board of director characteristics, and earnings management. Journal of Accounting and Economics, 33 (3), 375-400.

Kaufmann D., Kraay, A., and Mastruzzi, M. (2009). Governance matters VIII: Aggregate and individual governance indicators 1996-2008. Working paper, the World Bank.

Koh, P. S., Laplante, S. K., and Tong, Y. H. (2007). Accountability and value enhancement roles of corporate governance. Accounting and Finance, 47 (2), 305-333.

Landsman, W. R., Maydew, E. L., and Thornock, J. R. (2012). The information content of annual earnings announcements and mandatory adoption of IFRS. Journal of Accounting and Economics, 53 (1), 34-54.

Lang, M. H., Lins, K. V., and Miller, D. P. (2003). ADRs, analysts, and accuracy: Does cross listing in the United States improve a firm's information environment and increase market value? Journal of Accounting Research, 41 (2), 317-345.

Leuz, C., Nanda, D., and Wysocki, P. D. (2003). Earnings management and investor protection: an international comparison. Journal of Financial Economics, 69 (3), 505-527.

Peasnell, K. V., Pope, P. F., and Young, S. (2005). Board monitoring and earnings management: Do outside directors influence abnormal accruals? Journal of Business Finance \& Accounting, 32 (7-8), 1311-1346.

Petersen, M. A. (2009). Estimating standard errors in finance panel data sets: Comparing approaches. Review of Financial Studies, 22 (1), 435.

Pevzner, M., Xie, F., and Xin, X. (2015). When firms talk, do investors listen? The role of trust in stock market reactions to corporate earnings announcements. Journal of Financial Economics. 117 (1), 190-223.

Pucheta-Martínez, M. C., and De Fuentes, C. (2007). The impact of audit committee characteristics on the enhancement of the quality of financial reporting: An empirical study in the Spanish context. Corporate Governance: An International Review, 15 (6), 13941412 . 


\section{Appendix A. Definition of the variables}

\begin{tabular}{|c|c|}
\hline Variables & Definition \\
\hline AVOL & $\begin{array}{l}\text { The abnormal trading volume (AVOL) is the average trading volume } \\
\text { over the event period }(t=-1 \text { to } t=+1) \text { divided by the average } \\
\text { trading volume over the } 100 \text {-days estimation window }(t=-60 \text { to } \\
t=-10 \text { and } t=+10 \text { to } t=+60) \text {. }\end{array}$ \\
\hline AVAR & $\begin{array}{l}\text { The abnormal return variance (AVAR) is the natural log of the ratio } \\
\text { of the mean squared abnormal returns during the event window }(t=0 \\
\text { to } t=+1) \text {, with the event occurring at day } 0 \text {, divided by the abnormal } \\
\text { returns variance during the estimation window }(t=-120 \text { to } t=-10 \\
\text { and } t=+10 \text { to } t=+120) \text {. }\end{array}$ \\
\hline CAR & $\begin{array}{l}\text { The cumulative abnormal returns over the event period }(t=0 \text { to } \\
t=+1) \text {. }\end{array}$ \\
\hline INDEP_AC & Percentage of independent directors on the audit committee. \\
\hline INSTIT_CONTEXT & $\begin{array}{l}\text { A continuous variable equal to the Brown et al. (2014) total index in } \\
\text { the main analysis, or to the indices from the World Bank Group (in } \\
\text { section 4.3.). }\end{array}$ \\
\hline SUE & The ratio of the absolute surprise. \\
\hline SIZE & The natural logarithm of total assets. \\
\hline LEVERAGE & The long term debt-to-total assets ratio. \\
\hline MTB & The market-to-book ratio. \\
\hline D_LOSS & $\begin{array}{l}\text { An indicator variable taking the value } 1 \text { if the firm is announcing } \\
\text { negative EPS, and } 0 \text { otherwise. }\end{array}$ \\
\hline BIG_4 & $\begin{array}{l}\text { A dummy variable taking the value } 1 \text { if the announcing firm mandates } \\
\text { a Big } 4 \text { as external auditor, and } 0 \text { otherwise. }\end{array}$ \\
\hline ABN_ACC & $\begin{array}{l}\text { A measure of earnings management, equal to the residuals (the } \\
\text { abnormal accruals) of Francis et al. (2013)'s total accrual measure. }\end{array}$ \\
\hline REPOR_LAG & $\begin{array}{l}\text { The number of days between the fiscal year end and the earnings } \\
\text { announcement date. }\end{array}$ \\
\hline CROSS_LIST & $\begin{array}{l}\text { An indicator variable taking the value } 1 \text { if the firm is listed in the US } \\
\text { (NYSE), and } 0 \text { otherwise. }\end{array}$ \\
\hline EXPERIENCE & $\begin{array}{l}\text { The median number of years spent on the actual board by members } \\
\text { of the audit committee. }\end{array}$ \\
\hline AC_SIZE & The number of members on the audit committee. \\
\hline BOARD_SIZE & The number of directors on the board. \\
\hline FROM_50_TO_99 & $\begin{array}{l}\text { A dummy variable taking the value } 1 \text { if at least } 50 \% \text { of independent } \\
\text { member, but less than } 100 \% \text {, are sitting on the audit committee, and } \\
0 \text { otherwise. }\end{array}$ \\
\hline FULLY_INDEP & $\begin{array}{l}\text { A dummy variable taking the value } 1 \text { if } 100 \% \text { of independent members } \\
\text { are sitting on the audit committee, and } 0 \text { otherwise. }\end{array}$ \\
\hline Industry fixed effects & $\begin{array}{l}\text { Industry fixed effects based on the Industry Classification } \\
\text { Benchmark (ICB). }\end{array}$ \\
\hline Year fixed effects & Year fixed effects for the period 2006-2014. \\
\hline
\end{tabular}


Appendix B. Scores for the institutional context

\begin{tabular}{|c|c|c|c|c|c|c|}
\hline \multirow[b]{2}{*}{ Country } & \multicolumn{3}{|c|}{ Panel A. Brown et al. (2014) } & \multicolumn{3}{|c|}{ Panel B. World Bank Group** } \\
\hline & Enforcement & Audit & Total & Rule of Law & Regulatory Quality & Overall index \\
\hline Austria & 8 & 19 & 27 & 1.87 & 1.53 & 1.7 \\
\hline Belgium & 22 & 22 & 44 & 1.39 & 1.3 & 1.34 \\
\hline Denmark & 22 & 27 & 49 & 1.95 & 1.84 & 1.9 \\
\hline Finland & 12 & 20 & 32 & 1.97 & 1.76 & 1.86 \\
\hline France & 16 & 29 & 45 & 1.47 & 1.21 & 1.34 \\
\hline Germany & 21 & 23 & 44 & 1.71 & 1.57 & 1.64 \\
\hline Ireland & 12 & 29 & 41 & 1.74 & 1.72 & 1.73 \\
\hline Italy & 19 & 27 & 46 & 0.42 & 0.85 & 0.64 \\
\hline Netherlands & 19 & 24 & 43 & 1.83 & 1.75 & 1.79 \\
\hline Norway & 22 & 25 & 47 & 1.95 & 1.49 & 1.72 \\
\hline Portugal & 12 & 17 & 29 & 1.05 & 0.89 & 0.97 \\
\hline Spain & 16 & 26 & 42 & 1.12 & 1.08 & 1.1 \\
\hline Sweden & 9 & 25 & 34 & 1.94 & 1.72 & 1.83 \\
\hline Switzerland & 22 & 27 & 49 & 1.82 & 1.62 & 1.72 \\
\hline United Kingdom & 22 & 32 & 54 & 1.74 & 1.75 & 1.74 \\
\hline
\end{tabular}

${ }^{*}$ Scores for 2008.

** Average values for the period 2006-2014. 
Appendix C. Evolution over the period 2006-2014 (9 years) of the percentage of independent members on the $\mathrm{AC}$

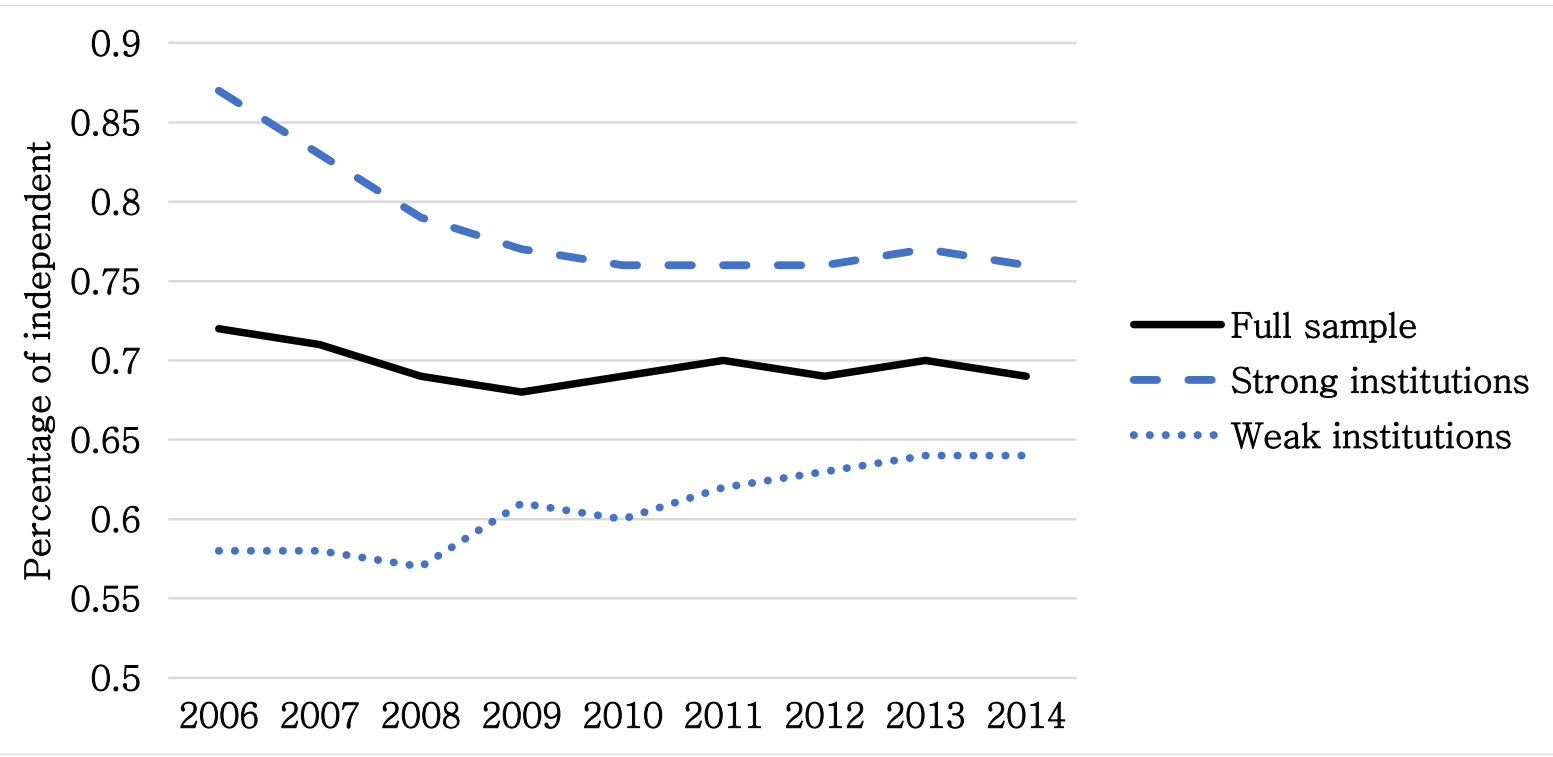




\section{Appendix D. Matrix of correlations}

\begin{tabular}{|c|c|c|c|c|c|c|c|c|c|c|c|c|c|c|c|c|}
\hline Variables & 1 & 2 & 3 & 4 & 5 & 6 & 7 & 8 & 9 & 10 & 11 & 12 & 13 & 14 & 15 & 16 \\
\hline 1. AVAR & 1.00 & & & & & & & & & & & & & & & \\
\hline 2. AVOL & $0.30 *$ & 1.00 & & & & & & & & & & & & & & \\
\hline 3. INDEP_AC & $0.10 *$ & $0.03 *$ & 1.00 & & & & & & & & & & & & & \\
\hline 4. INSTIT_CONTEXT & 0.02 & $0.07 *$ & $0.13 *$ & 1.00 & & & & & & & & & & & & \\
\hline 5. SUE & 0.03 & 0.03 & $0.05 *$ & $0.10 *$ & 1.00 & & & & & & & & & & & \\
\hline 6. SIZE & $0.08 *$ & $-0.17 *$ & $0.04 *$ & $-0.35 *$ & -0.02 & 1.00 & & & & & & & & & & \\
\hline 7. LEVERAGE & -0.01 & $-0.09 *$ & 0.00 & $-0.20 *$ & -0.02 & 0.00 & 1.00 & & & & & & & & & \\
\hline 8. MTB & $0.04 *$ & 0.00 & 0.02 & $0.06 *$ & $0.03 *$ & -0.03 & $-0.06 *$ & 1.00 & & & & & & & & \\
\hline 9. D_LOSS & $-0.11 *$ & -0.02 & $-0.09 *$ & $0.03 *$ & $-0.10 *$ & $-0.28 *$ & 0.00 & -0.03 & 1.00 & & & & & & & \\
\hline 10. BIG_4 & 0.02 & $-0.06 *$ & $0.13 *$ & $-0.13 *$ & 0.02 & $0.34 *$ & $0.14 *$ & 0.00 & $-0.10 *$ & 1.00 & & & & & & \\
\hline 11. ABNACC & 0.00 & 0.00 & -0.01 & 0.00 & $0.04 *$ & -0.01 & $-0.08 *$ & -0.02 & $-0.10 *$ & $-0.04 *$ & 1.00 & & & & & \\
\hline 12. REPORT_LAG & 0.01 & -0.01 & 0.02 & -0.01 & 0.00 & 0.00 & 0.00 & 0.00 & 0.00 & 0.01 & 0.00 & 1.00 & & & & \\
\hline 13. CROSS_LIST & $0.04 *$ & $-0.05 *$ & $0.06 *$ & 0.00 & 0.00 & $0.32 *$ & $0.13 *$ & $0.04 *$ & $-0.06 *$ & $0.07 *$ & -0.01 & -0.01 & 1.00 & & & \\
\hline 14. EXPERIENCE & 0.01 & 0.01 & $-0.15 *$ & $-0.11 *$ & 0.01 & -0.01 & $-0.05 *$ & -0.02 & $-0.06 *$ & $-0.06 *$ & -0.02 & -0.02 & -0.02 & 1.00 & & \\
\hline 15. AC_SIZE & 0.02 & $-0.10 *$ & $-0.08 *$ & $-0.20 *$ & -0.02 & $0.45 *$ & $0.14 *$ & 0.00 & $-0.11 *$ & $0.18 *$ & $0.16 *$ & 0.00 & $0.16 *$ & $-0.04 *$ & 1.00 & \\
\hline 16. BOARD_SIZE & 0.01 & $-0.13 *$ & $-0.24 *$ & $-0.36 *$ & $-0.05 *$ & $0.66 *$ & $0.23 *$ & $-0.04 *$ & $-0.14 *$ & $0.16 *$ & $0.21 *$ & $-0.04 *$ & $0.21 *$ & $0.08 *$ & $0.55 *$ & 1.00 \\
\hline
\end{tabular}

* statistical significance at the $1 \%$ threshold 
Table 1. Sample selection

\begin{tabular}{|c|c|c|}
\hline Criteria & $\begin{array}{l}\text { Unique } \\
\text { firms }\end{array}$ & $\begin{array}{l}\text { Firm- }^{-} \\
\text {years }\end{array}$ \\
\hline $\begin{array}{l}\text { European firms on Boardex excluding financials, insurance and real } \\
\text { estate since } 2006\end{array}$ & $3^{\prime} 216$ & 21 '322 \\
\hline Firms with at least 3 years of data in a row & 2'942 & $20 ' 864$ \\
\hline $\begin{array}{l}\text { Firms with data (EPS announcement dates, etc.) on Capital IQ and } \\
\text { Datastream }\end{array}$ & 1'812 & $13^{\prime} 874$ \\
\hline Firms with all data & 1'420 & 7’656 \\
\hline
\end{tabular}


Table 2. Sample composition by country and year

\begin{tabular}{l|ccccccccccc}
\hline \multirow{2}{*}{ Country } & \multicolumn{10}{|c}{ Year } \\
\cline { 2 - 11 } & 2006 & 2007 & 2008 & 2009 & 2010 & 2011 & 2012 & 2013 & 2014 & Total \\
\hline Austria & 6 & 15 & 18 & 18 & 16 & 17 & 17 & 16 & 13 & 136 \\
Belgium & 21 & 27 & 29 & 27 & 32 & 30 & 34 & 32 & 31 & 263 \\
Denmark & 2 & 3 & 6 & 9 & 14 & 20 & 21 & 20 & 18 & 113 \\
Finland & 16 & 20 & 20 & 20 & 24 & 27 & 31 & 30 & 31 & 219 \\
France & 89 & 99 & 109 & 127 & 116 & 135 & 146 & 144 & 137 & 1102 \\
Germany & 50 & 59 & 67 & 67 & 74 & 82 & 91 & 90 & 75 & 655 \\
Ireland & 8 & 11 & 19 & 20 & 19 & 17 & 17 & 17 & 14 & 142 \\
Italy & 14 & 17 & 17 & 15 & 16 & 16 & 8 & 10 & 11 & 124 \\
Netherlands & 22 & 24 & 26 & 34 & 31 & 32 & 24 & 28 & 28 & 249 \\
Norway & 9 & 15 & 18 & 19 & 32 & 35 & 33 & 31 & 29 & 221 \\
Portugal & 3 & 9 & 10 & 10 & 12 & 12 & 10 & 10 & 7 & 83 \\
Spain & 29 & 32 & 41 & 41 & 44 & 49 & 52 & 51 & 49 & 388 \\
Sweden & 33 & 33 & 36 & 46 & 43 & 50 & 45 & 47 & 40 & 373 \\
Switzerland & 29 & 28 & 30 & 31 & 37 & 38 & 35 & 33 & 26 & 287 \\
UK & 220 & 322 & 421 & 425 & 427 & 428 & 396 & 394 & 268 & 3301 \\
\hline \multicolumn{1}{c}{ Total } & 551 & 714 & 867 & 909 & 938 & 989 & 961 & 953 & 777 & 7656 \\
\hline
\end{tabular}


Table 3. Descriptive statistics

\begin{tabular}{lccccc}
\hline Variable & Mean & $\begin{array}{c}\text { Standard } \\
\text { deviation }\end{array}$ & $\begin{array}{c}\text { First } \\
\text { quartile }\end{array}$ & Median & $\begin{array}{c}\text { Third } \\
\text { quartile }\end{array}$ \\
\hline A. Full sample (7656 observations) & & & & & \\
AVAR & 0.59 & 1.85 & -0.45 & 0.80 & 1.88 \\
AVOL & 2.10 & 1.97 & 1.06 & 1.60 & 2.43 \\
INDEP_AC & 0.70 & 0.37 & 0.50 & 1.00 & 1.00 \\
SUE & 0.25 & 2.04 & -0.33 & 0.00 & 0.75 \\
SIZE & 13.49 & 2.15 & 12.02 & 13.52 & 14.95 \\
LEVERAGE & 0.21 & 0.17 & 0.07 & 0.20 & 0.32 \\
MTB & 2.45 & 2.95 & 1.02 & 1.72 & 2.89 \\
D_LOSS & 0.15 & 0.36 & 0.00 & 0.00 & 0.00 \\
BIG_4 & 0.78 & 0.41 & 1.00 & 1.00 & 1.00 \\
ABN_ACC & 0.00 & 0.08 & -0.03 & 0.00 & 0.03 \\
REPORT_LAG & 66.72 & 22.37 & 52.00 & 63.00 & 79.00 \\
CROSS_LIST & 0.04 & 0.19 & 0.00 & 0.00 & 0.00 \\
EXPERIENCE & 5.38 & 3.70 & 2.80 & 4.70 & 6.95 \\
AC_SIZE & 3.30 & 1.16 & 3.00 & 3.00 & 4.00 \\
BOARD_SIZE & 9.35 & 4.16 & 6.00 & 8.00 & 11.00 \\
\hline
\end{tabular}

${ }^{a}$ 6’732 observations due to missing data 
Table 3. (Continued)

\begin{tabular}{|c|c|c|c|c|c|}
\hline Variable & Mean & $\begin{array}{l}\text { Standard } \\
\text { deviation }\end{array}$ & $\begin{array}{c}\text { First } \\
\text { quartile }\end{array}$ & Median & $\begin{array}{c}\text { Third } \\
\text { Quartile }\end{array}$ \\
\hline \multicolumn{6}{|c|}{ B. Countries with strong institutions (3922 observations) } \\
\hline AVAR & 0.65 & 1.93 & -0.40 & 0.86 & 1.97 \\
\hline $\mathrm{AVOL}^{\mathrm{b}}$ & 2.27 & 2.30 & 1.06 & 1.63 & 2.59 \\
\hline INDEP_AC & 0.78 & 0.36 & 0.67 & 1.00 & 1.00 \\
\hline SUE & 0.44 & 2.20 & -0.09 & 0.00 & 0.91 \\
\hline SIZE & 12.69 & 2.14 & 11.15 & 12.66 & 14.21 \\
\hline LEVERAGE & 0.18 & 0.17 & 0.02 & 0.15 & 0.29 \\
\hline MTB & 2.67 & 3.44 & 0.98 & 1.75 & 3.15 \\
\hline D_LOSS & 0.16 & 0.37 & 0.00 & 0.00 & 0.00 \\
\hline BIG_4 & 0.76 & 0.43 & 1.00 & 1.00 & 1.00 \\
\hline ABN_ACC & 0.00 & 0.09 & -0.04 & 0.00 & 0.04 \\
\hline REPORT_LAG & 66.51 & 22.25 & 52.00 & 63.00 & 78.00 \\
\hline CROSS_LIST & 0.03 & 0.18 & 0.00 & 0.00 & 0.00 \\
\hline EXPERIENCE & 4.82 & 3.20 & 2.70 & 4.20 & 6.10 \\
\hline AC_SIZE & 3.06 & 0.96 & 2.00 & 3.00 & 4.00 \\
\hline BOARD_SIZE & 7.39 & 2.32 & 6.00 & 7.00 & 9.00 \\
\hline \multicolumn{6}{|c|}{ C. Countries with weak institutions (3734 observations) } \\
\hline AVAR & 0.53 & 1.77 & -0.50 & 0.71 & 1.76 \\
\hline $\mathrm{AVOL}^{\mathrm{c}}$ & 1.92 & 1.54 & 1.07 & 1.57 & 2.32 \\
\hline INDEP_AC & 0.61 & 0.36 & 0.33 & 0.67 & 1.00 \\
\hline SUE & 0.05 & 1.84 & -0.51 & 0.00 & 0.60 \\
\hline SIZE & 14.33 & 1.82 & 13.07 & 14.29 & 15.48 \\
\hline LEVERAGE & 0.24 & 0.16 & 0.12 & 0.24 & 0.34 \\
\hline MTB & 2.20 & 2.29 & 1.06 & 1.69 & 2.66 \\
\hline D_LOSS & 0.14 & 0.34 & 0.00 & 0.00 & 0.00 \\
\hline BIG_4 & 0.81 & 0.39 & 1.00 & 1.00 & 1.00 \\
\hline ABN_ACC & 0.00 & 0.07 & -0.02 & 0.00 & 0.03 \\
\hline REPORT_LAG & 66.94 & 22.50 & 52.00 & 64.00 & 79.00 \\
\hline CROSS_LIST & 0.05 & 0.21 & 0.00 & 0.00 & 0.00 \\
\hline EXPERIENCE & 5.96 & 4.07 & 3.20 & 5.20 & 7.80 \\
\hline AC_SIZE & 3.55 & 1.29 & 3.00 & 3.00 & 4.00 \\
\hline BOARD_SIZE & 11.40 & 4.64 & 8.00 & 10.00 & 14.00 \\
\hline
\end{tabular}

b 3'357 observations due to missing data

c 3'375 observations due to missing data 
Table 4. Description of the levels of independence by number of members sitting on the audit committee

\begin{tabular}{c|ccc|ccc|ccc}
\hline $\begin{array}{c}\text { Percentage of } \\
\text { Independent members }\end{array}$ & \multicolumn{3}{|c|}{$<50 \%$} & & \multicolumn{2}{|c|}{$>=50 \%$ and $<100 \%$} & \multicolumn{3}{|c}{$100 \%$} \\
\hline $\begin{array}{c}\text { Institutional } \\
\text { Setting }\end{array}$ & Weak & Strong & All & Weak & Strong & All & Weak & Strong & All \\
\hline Full sample & $30 \%$ & $17 \%$ & $24 \%$ & $36 \%$ & $15 \%$ & $25 \%$ & $34 \%$ & $67 \%$ & $51 \%$ \\
\hline 2 members & $19 \%$ & $23 \%$ & $21 \%$ & $25 \%$ & $15 \%$ & $18 \%$ & $56 \%$ & $63 \%$ & $61 \%$ \\
3 members & $25 \%$ & $19 \%$ & $22 \%$ & $36 \%$ & $15 \%$ & $25 \%$ & $39 \%$ & $66 \%$ & $53 \%$ \\
4 members & $32 \%$ & $9 \%$ & $21 \%$ & $42 \%$ & $18 \%$ & $31 \%$ & $27 \%$ & $73 \%$ & $48 \%$ \\
5 members & $40 \%$ & $2 \%$ & $25 \%$ & $43 \%$ & $16 \%$ & $32 \%$ & $17 \%$ & $82 \%$ & $42 \%$ \\
6 members & $65 \%$ & $2 \%$ & $55 \%$ & $28 \%$ & $22 \%$ & $27 \%$ & $7 \%$ & $76 \%$ & $18 \%$ \\
Other cases & $50 \%$ & $41 \%$ & $46 \%$ & $24 \%$ & $3 \%$ & $16 \%$ & $26 \%$ & $55 \%$ & $37 \%$ \\
\hline
\end{tabular}




\section{Table 5. Impact of the AC's independence on the market reaction}

This table reports the results of the tests of models 2 and 3 using the abnormal returns variance (AVAR) and the abnormal trading volume (AVOL) as measures of market reaction. INDEP_AC is the percentage of independent members in the audit committee. INSTIT_CONTEXT is the Brown et al. (2014) total index. SUE is the ratio of the absolute surprise divided by the standard deviation of analysts' estimates. SIZE is the natural logarithm of total assets in euros. LEVERAGE is the ratio of total liabilities divided by total assets. MTB is the market value of equity divided by the book value of equity. D_LOSS is a dummy variable that takes the value 1 if the EPS is negative, and 0 otherwise. BIG_4 is a dummy variable that takes the value 1 if the announcing firm's auditor is a Big 4 and 0 otherwise. ABN_ACC equals to the residuals (the abnormal accruals) of a total normal accruals model following Francis et al. (2013). REPORT_LAG is the number of days between fiscal year end and the announcement date for a given year. CROSS_LIST is a dummy variable that is equal to 1 if the announcing firm is listed in the US and 0 otherwise. EXPERIENCE is the median number of years for all audit committee members spent on the board of the announcing firm. AC_SIZE is the number of members on the audit committee. BOARD_SIZE is the number of directors sitting on the board. Robust $z^{-}$ statistics are in parentheses based on standard errors adjusted for heteroscedasticity and firmlevel clustering. $* * *$ and $* * *$ represents statistical significance at the $10 \%, 5 \%$ and $1 \%$ thresholds.

\begin{tabular}{|c|c|c|c|c|}
\hline & $\begin{array}{c}(1) \\
\text { AVAR }\end{array}$ & $\begin{array}{c}(2) \\
\text { AVAR }\end{array}$ & $\begin{array}{c}(3) \\
\text { AVOL } \\
\end{array}$ & $\begin{array}{c}(4) \\
\text { AVOL } \\
\end{array}$ \\
\hline Constant & $\begin{array}{c}-1.11 * * * \\
(-3.36)\end{array}$ & $\begin{array}{l}-2.95 * * * \\
(-4.75)\end{array}$ & $\begin{array}{l}4.22 * * * \\
(13.59)\end{array}$ & $\begin{array}{c}3.12 * * * \\
(5.56)\end{array}$ \\
\hline INDEP_AC & $\begin{array}{c}0.40 * * * \\
(5.19)\end{array}$ & $\begin{array}{c}2.54 * * * \\
(4.17)\end{array}$ & $\begin{array}{c}0.14 * \\
(1.83)\end{array}$ & $\begin{array}{l}1.41 * * \\
(2.51)\end{array}$ \\
\hline INSTIT_CONTEXT & $\begin{array}{l}0.01 * \\
(1.82)\end{array}$ & $\begin{array}{c}0.04 * * * \\
(3.89)\end{array}$ & $\begin{array}{c}0.00 \\
(0.78)\end{array}$ & $\begin{array}{l}0.02 * * \\
(2.33)\end{array}$ \\
\hline INDEP_AC $*$ INSTIT_CONTEXT & & $\begin{array}{c}-0.05 * * * \\
(-3.52)\end{array}$ & & $\begin{array}{c}-0.03 * * \\
(-2.19)\end{array}$ \\
\hline SUE & $\begin{array}{c}0.00 \\
(0.35)\end{array}$ & $\begin{array}{c}0.00 \\
(0.32)\end{array}$ & $\begin{array}{c}0.01 \\
(0.70)\end{array}$ & $\begin{array}{c}0.01 \\
(0.70)\end{array}$ \\
\hline SIZE & $\begin{array}{c}0.10 * * * \\
(5.18)\end{array}$ & $\begin{array}{c}0.10 * * * \\
(5.34)\end{array}$ & $\begin{array}{c}-0.14 * * * \\
(-8.05)\end{array}$ & $\begin{array}{c}-0.14 * * * \\
(-7.96)\end{array}$ \\
\hline LEVERAGE & $\begin{array}{c}-0.41 * * \\
(-2.42)\end{array}$ & $\begin{array}{l}-0.41 * * \\
(-2.45)\end{array}$ & $\begin{array}{l}-0.28 * \\
(-1.85)\end{array}$ & $\begin{array}{l}-0.29 * \\
(-1.86)\end{array}$ \\
\hline MTB & $\begin{array}{c}0.02 * * \\
(2.33)\end{array}$ & $\begin{array}{c}0.02 * * \\
(2.37)\end{array}$ & $\begin{array}{c}-0.01 \\
(-1.17)\end{array}$ & $\begin{array}{c}-0.01 \\
(-1.15)\end{array}$ \\
\hline D_LOSS & $\begin{array}{c}-0.38 * * * \\
(-4.79)\end{array}$ & $\begin{array}{c}-0.40 * * * \\
(-5.03)\end{array}$ & $\begin{array}{c}-0.31 * * * \\
(-3.70)\end{array}$ & $\begin{array}{c}-0.32 * * * \\
(-3.81)\end{array}$ \\
\hline BIG_4 & $\begin{array}{c}-0.09 \\
(-1.35)\end{array}$ & $\begin{array}{c}-0.07 \\
(-1.04)\end{array}$ & $\begin{array}{c}-0.04 \\
(-0.58)\end{array}$ & $\begin{array}{c}-0.03 \\
(-0.41)\end{array}$ \\
\hline ABN_ACC & $\begin{array}{l}-0.22 \\
(-0.77)\end{array}$ & $\begin{array}{c}-0.24 \\
(-0.85)\end{array}$ & $\begin{array}{l}-0.32 \\
(-0.91)\end{array}$ & $\begin{array}{l}-0.33 \\
(-0.94)\end{array}$ \\
\hline REPORT_LAG & $\begin{array}{c}0.00 \\
(0.37)\end{array}$ & $\begin{array}{c}0.00 \\
(0.31)\end{array}$ & $\begin{array}{l}-0.00 \\
(-0.57)\end{array}$ & $\begin{array}{l}-0.00 \\
(-0.61)\end{array}$ \\
\hline CROSS_LIST & $\begin{array}{c}0.08 \\
(0.66)\end{array}$ & $\begin{array}{c}0.04 \\
(0.36)\end{array}$ & $\begin{array}{l}0.19 * * \\
(2.40)\end{array}$ & $\begin{array}{l}0.17 * * \\
(2.16)\end{array}$ \\
\hline
\end{tabular}




\begin{tabular}{l|cc|cc} 
EXPERIENCE & 0.01 & 0.01 & 0.00 & -0.00 \\
AC_SIZE & $(1.36)$ & $(1.33)$ & $(0.00)$ & $(-0.02)$ \\
& 0.01 & 0.01 & $-0.04 * *$ & $-0.04 *$ \\
BOARD_SIZE & $(0.32)$ & $(0.55)$ & $(-2.09)$ & $(-1.86)$ \\
& $-0.02 * *$ & -0.01 & -0.00 & -0.00 \\
Time FE & $(-2.15)$ & $(-1.50)$ & $(-0.43)$ & $(-0.04)$ \\
Industry FE & YES & YES & YES & YES \\
Cluster & YES & YES & YES & YES \\
\hline Observations & Firm & Firm & Firm & Firm \\
R-squared & 7,656 & 7,656 & 6,732 & 6.732 \\
F-statistic & 0.04 & 0.04 & 0.04 & 0.04 \\
\hline
\end{tabular}




\section{Table 6. Impact of the AC's independence on the market reaction in different institutional contexts}

This table reports the results of the tests of models 1 using the abnormal returns variance (AVAR) and the abnormal trading volume (AVOL) as measures of market reaction. The "Strong institutions" subsample is composed of firms in countries with Brown et al. total index above the sample median, while the "Weak institutions" subsample includes firms in countries with Brown et al. total index equal or below the sample median. INDEP_AC is the percentage of independent members in the audit committee. SUE is the ratio of the absolute surprise divided by the standard deviation of analysts' estimates. SIZE is the natural logarithm of total assets in euros. LEVERAGE is the ratio of total liabilities divided by total assets. MTB is the market value of equity divided by the book value of equity. D_LOSS is a dummy variable that takes the value 1 if the EPS is negative, and 0 otherwise. BIG_4 is a dummy variable that takes the value 1 if the announcing firm's auditor is a Big 4 and 0 otherwise. ABN_ACC equals to the residuals (the abnormal accruals) of a total normal accruals model following Francis et al. (2013). REPORT_LAG is the number of days between fiscal year end and the announcement date for a given year. CROSS_LIST is a dummy variable that is equal to 1 if the announcing firm is listed in the US and 0 otherwise. EXPERIENCE is the median number of years for all audit committee members spent on the board of the announcing firm. AC_SIZE is the number of members on the audit committee. BOARD_SIZE is the number of directors sitting on the board. Robust $z^{-}$ statistics are in parentheses based on standard errors adjusted for heteroscedasticity and firmlevel clustering. $*, * *$ and $* * *$ represents statistical significance at the $10 \%, 5 \%$ and $1 \%$ thresholds.

\begin{tabular}{|c|c|c|c|c|c|c|}
\hline & \multicolumn{2}{|c|}{$\begin{array}{c}\text { Full } \\
\text { sample }\end{array}$} & \multicolumn{2}{|c|}{$\begin{array}{c}\text { Strong } \\
\text { institutions }\end{array}$} & \multicolumn{2}{|c|}{$\begin{array}{c}\text { Weak } \\
\text { institutions }\end{array}$} \\
\hline & $\begin{array}{c}(1) \\
\text { AVAR }\end{array}$ & $\begin{array}{c}(2) \\
\text { AVOL }\end{array}$ & $\begin{array}{c}(3) \\
\text { AVAR }\end{array}$ & $\begin{array}{c}(4) \\
\text { AVOL }\end{array}$ & $\begin{array}{c}(5) \\
\text { AVAR }\end{array}$ & $\begin{array}{c}6) \\
\text { AVOL }\end{array}$ \\
\hline Constant & $\begin{array}{c}-0.66 * * * \\
(-2.89)\end{array}$ & $\begin{array}{l}4.39 * * * \\
(16.80)\end{array}$ & $\begin{array}{l}-0.02 \\
(-0.06)\end{array}$ & $\begin{array}{l}4.85 * * * \\
(11.84)\end{array}$ & $\begin{array}{c}-1.90 * * * \\
(-5.28)\end{array}$ & $\begin{array}{c}3.39 * * * \\
(9.78)\end{array}$ \\
\hline INDEP_AC & $\begin{array}{c}0.41 * * * \\
(5.32)\end{array}$ & $\begin{array}{l}0.15 * \\
(1.88)\end{array}$ & $\begin{array}{c}0.17 \\
(1.56)\end{array}$ & $\begin{array}{c}0.07 \\
(0.58)\end{array}$ & $\begin{array}{c}0.56 * * * \\
(5.04)\end{array}$ & $\begin{array}{l}0.22 * * \\
(2.10)\end{array}$ \\
\hline SUE & $\begin{array}{c}0.01 \\
(0.51)\end{array}$ & $\begin{array}{c}0.01 \\
(0.75)\end{array}$ & $\begin{array}{c}0.01 \\
(0.61)\end{array}$ & $\begin{array}{c}0.02 \\
(0.82)\end{array}$ & $\begin{array}{c}-0.01 \\
(-0.34)\end{array}$ & $\begin{array}{c}-0.00 \\
(-0.13)\end{array}$ \\
\hline SIZE & $\begin{array}{c}0.09 * * * \\
(4.95)\end{array}$ & $\begin{array}{c}-0.15 * * * \\
(-8.14)\end{array}$ & $\begin{array}{c}0.04 \\
(1.41)\end{array}$ & $\begin{array}{c}-0.16 * * * \\
(-5.45)\end{array}$ & $\begin{array}{c}0.17 * * * \\
(6.12)\end{array}$ & $\begin{array}{c}-0.08 * * * \\
(-3.33)\end{array}$ \\
\hline LEVERAGE & $\begin{array}{c}-0.44 * * * \\
(-2.59)\end{array}$ & $\begin{array}{c}-0.29 * \\
(-1.92)\end{array}$ & $\begin{array}{l}-0.20 \\
(-0.84)\end{array}$ & $\begin{array}{c}-0.02 \\
(-0.08)\end{array}$ & $\begin{array}{c}-0.68 * * * \\
(-2.85)\end{array}$ & $\begin{array}{c}-0.57 * * * \\
(-2.92)\end{array}$ \\
\hline MTB & $\begin{array}{l}0.02 * * \\
(2.37)\end{array}$ & $\begin{array}{c}-0.01 \\
(-1.16)\end{array}$ & $\begin{array}{l}0.01 * \\
(1.84)\end{array}$ & $\begin{array}{c}-0.01 \\
(-0.50)\end{array}$ & $\begin{array}{c}0.02 \\
(1.43)\end{array}$ & $\begin{array}{c}-0.01 \\
(-0.78)\end{array}$ \\
\hline D_LOSS & $\begin{array}{c}-0.39 * * * \\
(-4.87)\end{array}$ & $\begin{array}{c}-0.31 * * * \\
(-3.73)\end{array}$ & $\begin{array}{c}-0.59 * * * \\
(-4.84)\end{array}$ & $\begin{array}{c}-0.49 * * * \\
(-3.59)\end{array}$ & $\begin{array}{l}-0.18 * \\
(-1.85)\end{array}$ & $\begin{array}{c}-0.10 \\
(-1.03)\end{array}$ \\
\hline BIG_4 & $\begin{array}{c}-0.09 \\
(-1.44)\end{array}$ & $\begin{array}{c}-0.05 \\
(-0.60)\end{array}$ & $\begin{array}{c}-0.05 \\
(-0.50)\end{array}$ & $\begin{array}{c}0.00 \\
(0.00)\end{array}$ & $\begin{array}{l}-0.09 \\
(-0.95)\end{array}$ & $\begin{array}{c}-0.07 \\
(-0.84)\end{array}$ \\
\hline ABN_ACC & $\begin{array}{c}-0.23 \\
(-0.81)\end{array}$ & $\begin{array}{c}-0.33 \\
(-0.92)\end{array}$ & $\begin{array}{c}-0.32 \\
(-0.87)\end{array}$ & $\begin{array}{l}-0.49 \\
(-0.97)\end{array}$ & $\begin{array}{l}-0.04 \\
(-0.09)\end{array}$ & $\begin{array}{c}0.03 \\
(0.07)\end{array}$ \\
\hline REPORT_LAG & $\begin{array}{c}0.00 \\
(0.38)\end{array}$ & $\begin{array}{l}-0.00 \\
(-0.58)\end{array}$ & $\begin{array}{c}0.00 \\
(1.12)\end{array}$ & $\begin{array}{c}-0.00 \\
(-0.43)\end{array}$ & $\begin{array}{l}-0.00 \\
(-0.35)\end{array}$ & $\begin{array}{l}-0.00 \\
(-0.21)\end{array}$ \\
\hline CROSS_LIST & $\begin{array}{c}0.11 \\
(0.93)\end{array}$ & $\begin{array}{l}0.20 * * \\
(2.55)\end{array}$ & $\begin{array}{c}0.12 \\
(0.74)\end{array}$ & $\begin{array}{l}0.28 * * \\
(2.25)\end{array}$ & $\begin{array}{c}0.02 \\
(0.12)\end{array}$ & $\begin{array}{c}0.11 \\
(1.13)\end{array}$ \\
\hline
\end{tabular}




\begin{tabular}{l|cc|cc|cc} 
EXPERIENCE & 0.01 & -0.00 & 0.01 & 0.02 & 0.00 & -0.01 \\
& $(1.16)$ & $(-0.06)$ & $(1.10)$ & $(1.27)$ & $(0.52)$ & $(-1.23)$ \\
AC_SIZE & 0.01 & $-0.04 *$ & -0.06 & $-0.12 * * *$ & 0.04 & -0.00 \\
& $(0.34)$ & $(-2.08)$ & $(-1.48)$ & $(-2.75)$ & $(1.38)$ & $(-0.09)$ \\
BOARD_SIZE & $-0.02 * *$ & -0.00 & 0.03 & -0.01 & $-0.03 * *$ & -0.01 \\
& $(-2.41)$ & $(-0.53)$ & $(1.52)$ & $(-0.31)$ & $(-2.49)$ & $(-0.68)$ \\
Time FE & YES & YES & YES & YES & YES & YES \\
Industry FE & YES & YES & YES & YES & YES & YES \\
Cluster & Firm & Firm & Firm & Firm & Firm & Firm \\
\hline Observations & 7,656 & 6,732 & 3,922 & 3,357 & 3,734 & 3,375 \\
R-squared & 0.04 & 0.04 & 0.03 & 0.05 & 0.05 & 0.04 \\
F-statistic & $7.39 * * *$ & $9.05 * * *$ & $3.61 * * *$ & $6.11 * * *$ & $6.15 * * *$ & $4.99 * * *$ \\
\hline
\end{tabular}




\section{Table 7. Impact of the AC's independence on the market reaction with the sub-indices from Brown et al. (2014)}

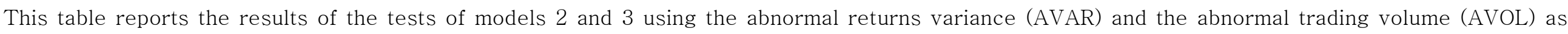

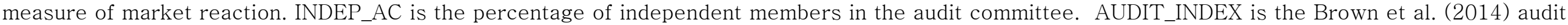

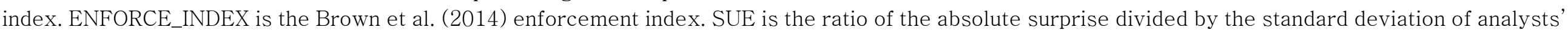

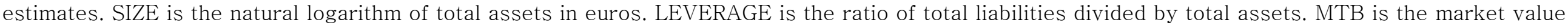

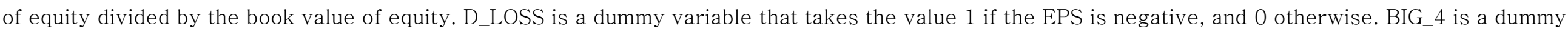

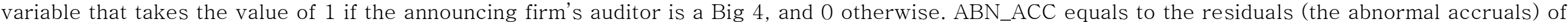

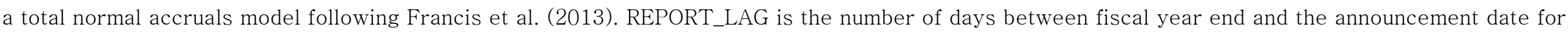

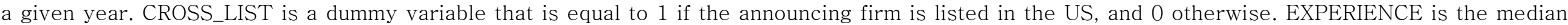

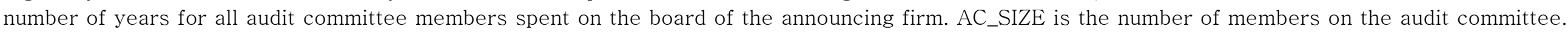

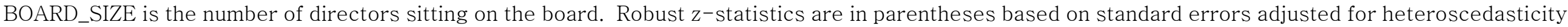
and firm-level clustering. *,** and *** represents statistical significance at the $10 \%, 5 \%$ and $1 \%$ thresholds.

\begin{tabular}{|c|c|c|c|c|c|c|c|c|}
\hline & \multicolumn{4}{|c|}{ Audit index } & \multicolumn{4}{|c|}{ Enforcement index } \\
\hline & $\begin{array}{c}\text { (1) } \\
\text { AVAR }\end{array}$ & $\begin{array}{c}(2) \\
\text { AVAR }\end{array}$ & $\begin{array}{c}(3) \\
\text { AVOL }\end{array}$ & $\begin{array}{c}(4) \\
\text { AVOL }\end{array}$ & $\begin{array}{c}(5) \\
\text { AVAR }\end{array}$ & $\begin{array}{c}(6) \\
\text { AVAR }\end{array}$ & $\begin{array}{c}(7) \\
\text { AVOL }\end{array}$ & $\begin{array}{c}(8) \\
\text { AVOL }\end{array}$ \\
\hline Constant & $\begin{array}{c}-1.18 * * * \\
(-3.57)\end{array}$ & $\begin{array}{c}-2.36 * * * \\
(-4.51)\end{array}$ & $\begin{array}{l}4.28 * * * \\
(13.34)\end{array}$ & $\begin{array}{c}3.88 * * * \\
(6.91)\end{array}$ & $\begin{array}{c}-0.86 * * * \\
(-3.03)\end{array}$ & $\begin{array}{c}-1.67 * * * \\
(-3.56)\end{array}$ & $\begin{array}{l}4.26 * * * \\
(14.99)\end{array}$ & $\begin{array}{c}3.49 * * * \\
(9.63)\end{array}$ \\
\hline INDEP_AC & $\begin{array}{c}0.38 * * * \\
(4.76)\end{array}$ & $\begin{array}{l}1.89 * * * \\
(3.61)\end{array}$ & $\begin{array}{l}0.14 * \\
(1.74)\end{array}$ & $\begin{array}{c}0.65 \\
(1.17)\end{array}$ & $\begin{array}{c}0.42 * * * \\
(5.41)\end{array}$ & $\begin{array}{c}1.43 * * * \\
(3.18)\end{array}$ & $\begin{array}{l}0.15 * \\
(1.94)\end{array}$ & $\begin{array}{c}1.11 * * * \\
(3.29)\end{array}$ \\
\hline AUDIT_INDEX & $\begin{array}{l}0.01 * * \\
(2.07)\end{array}$ & $\begin{array}{c}0.06 * * * \\
(3.46)\end{array}$ & $\begin{array}{c}0.00 \\
(0.48)\end{array}$ & $\begin{array}{c}0.02 \\
(0.98)\end{array}$ & & & & \\
\hline INDEP_AC * AUDIT_INDEX & & $\begin{array}{c}-0.05 * * * \\
(-2.88)\end{array}$ & & $\begin{array}{c}-0.02 \\
(-0.90)\end{array}$ & & & & \\
\hline ENFORCE_INDEX & & & & & $\begin{array}{c}0.01 \\
(1.17)\end{array}$ & $\begin{array}{l}0.05 * * \\
(2.48)\end{array}$ & $\begin{array}{c}0.00 \\
(0.86)\end{array}$ & $\begin{array}{c}0.04 * * * \\
(2.96)\end{array}$ \\
\hline $\begin{array}{l}\text { INDEP_AC * } \\
\text { ENFORCE_INDEX }\end{array}$ & & & & & & $\begin{array}{l}-0.05 * * \\
(-2.29)\end{array}$ & & $\begin{array}{c}-0.05 * * * \\
(-2.76)\end{array}$ \\
\hline
\end{tabular}




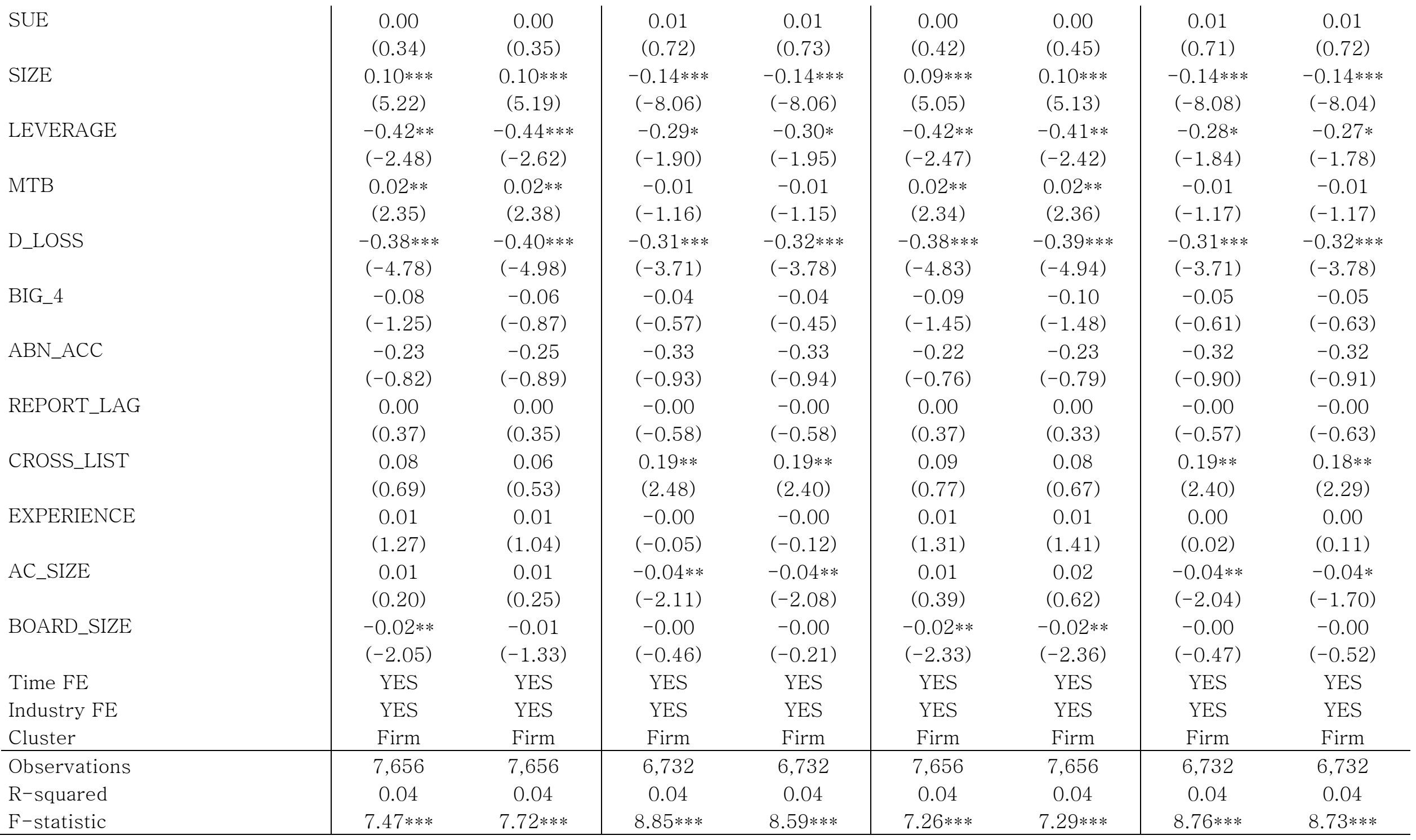




\section{Table 8. Impact of the AC's independence on the market reaction with sub-indices and sub-samples}

This table reports the results of the tests of model 1 using the abnormal returns variance (AVAR) and the abnormal trading volume (AVOL) as market reaction proxies. The "Strong audit index" subsample is composed of firms in countries with Brown et al. audit index above the sample median, while the "Weak audit index" subsample includes firms in countries with Brown et al. audit index equal or below the sample median. The "Strong enforcement index" subsample is composed of firms in countries with Brown et al. enforcement index above the sample median, while the "Weak enforcement index" subsample includes firms in countries with Brown et al. enforcement index equal or below the sample median. INDEP_AC is the percentage of independent members in the audit committee. AUDIT_INDEX is the Brown et al. (2014) audit index. ENFORCE_INDEX is the Brown et al. (2014) enforcement index. SUE is the ratio of the absolute surprise divided by the standard deviation of analysts' estimates. SIZE is the natural logarithm of total assets in euros. LEVERAGE is the ratio of total liabilities divided by total assets. MTB is the market value of equity divided by the book value of equity. D_LOSS is a dummy variable that takes the value 1 if the EPS is negative, and 0 otherwise. BIG_4 is a dummy variable that takes the value of 1 if the announcing firm's auditor is a Big 4, and 0 otherwise. ABN_ACC equals to the residuals (the abnormal accruals) of a total normal accruals model following Francis et al. (2013). REPORT_LAG is the number of days between fiscal year end and the announcement date for a given year. CROSS_LIST is a dummy variable that is equal to 1 if the announcing firm is listed in the US, and 0 otherwise. EXPERIENCE is the median number of years for all audit committee members spent on the board of the announcing firm. AC_SIZE is the number of members on the audit committee. BOARD_SIZE is the number of directors sitting on the board. Robust $z^{-}$ statistics are in parentheses based on standard errors adjusted for heteroscedasticity and firm-level clustering. *, ** and *** represents statistical significance at the $10 \%, 5 \%$ and $1 \%$ thresholds.

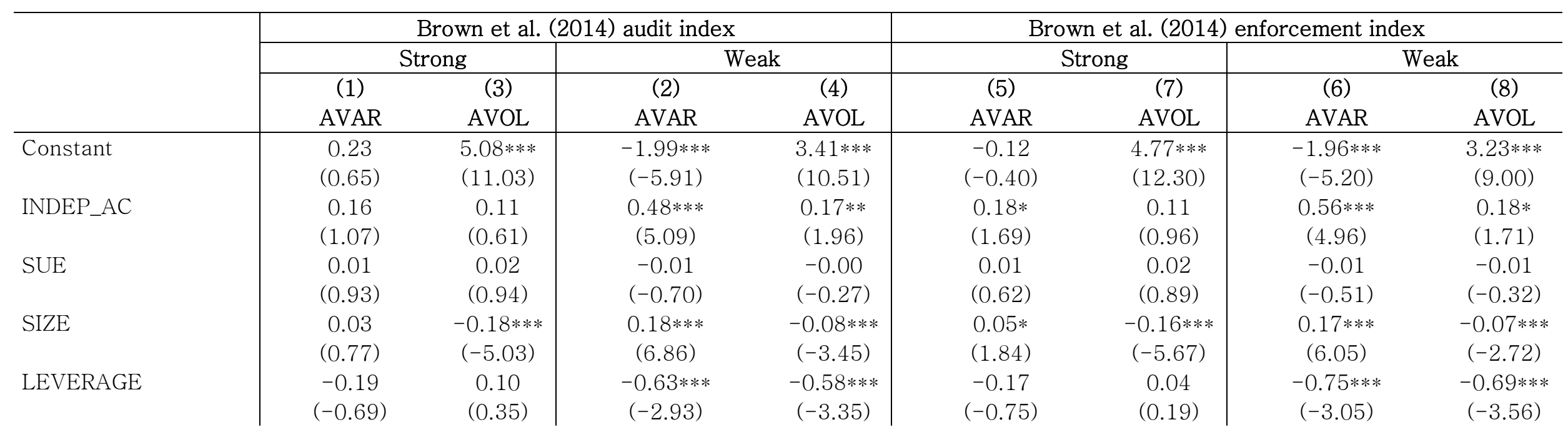




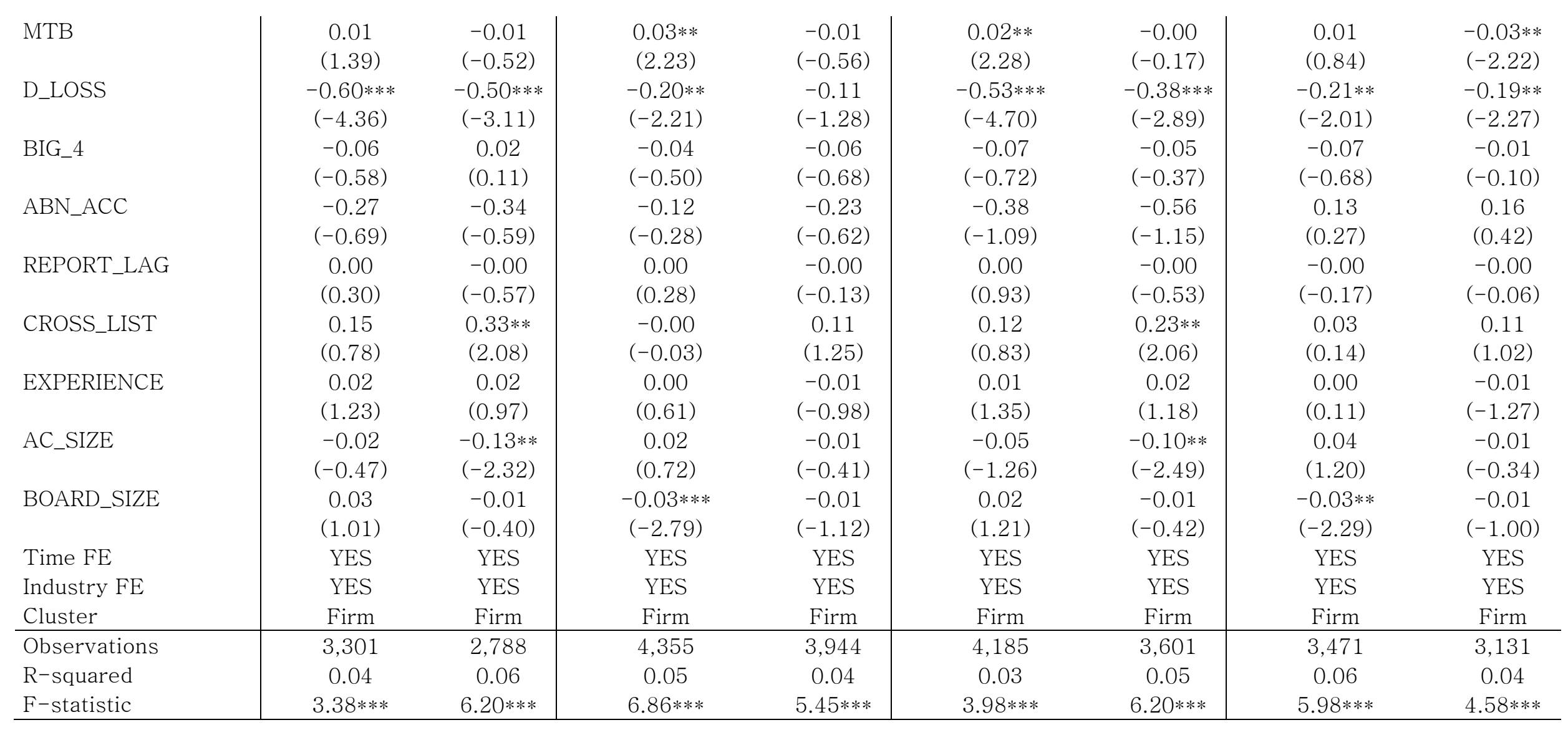


Table 9. Impact of the levels of independence and the size of the audit committee on the market reaction

This table reports the results of the tests of model 1 using the abnormal returns variance (AVAR) as market reaction proxy. For each audit committee size, the table discloses the results for three different samples. First, all firms with the corresponding number of audit committee members. Second, firms in the "Strong" subsample, which is composed of firms in countries with Brown et al. total index above the sample median. Third, firms in the "Weak" subsample, which includes firms in countries with Brown et al. total index equal or below the sample median. FROM_50_TO_99 is a dummy variable taking the value 1 if at least $50 \%$ of independent member, but less than $100 \%$, are sitting on the audit committee, and 0 otherwise. FULLY_INDEP is a dummy variable taking the value 1 if $100 \%$ of independent members are sitting on the audit committee, and 0 otherwise. SUE is the ratio of the absolute surprise divided by the standard deviation of analysts' estimates. SIZE is the natural logarithm of total assets in euros. LEVERAGE is the ratio of total liabilities divided by total assets. MTB is the market value of equity divided by the book value of equity. D_LOSS is a dummy variable that takes the value 1 if the EPS is negative, and 0 otherwise. BIG_4 is a dummy variable that takes the value of 1 if the announcing firm's auditor is a Big 4, and 0 otherwise. ABN_ACC equals to the residuals (the abnormal accruals) of a total normal accruals model following Francis et al. (2013). REPORT_LAG is the number of days between fiscal year end and the announcement date for a given year. CROSS_LIST is a dummy variable that is equal to 1 if the announcing firm is listed in the US, and 0 otherwise. EXPERIENCE is the median number of years for all audit committee members spent on the board of the announcing firm. BOARD_SIZE is the

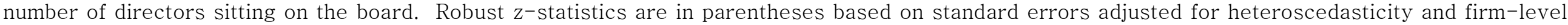
clustering. $*, * *$ and $* * *$ represents statistical significance at the $10 \%, 5 \%$ and $1 \%$ thresholds.

\begin{tabular}{|c|c|c|c|c|c|c|c|c|c|c|c|c|}
\hline & \multicolumn{3}{|c|}{$\mathrm{AC}$ size $=2$} & \multicolumn{3}{|c|}{$\mathrm{AC}$ size $=3$} & \multicolumn{3}{|c|}{$\mathrm{AC}$ size $=4$} & \multicolumn{3}{|c|}{$\mathrm{AC}$ size $=5$} \\
\hline & All & Strong & Weak & All & Strong & Weak & All & Strong & Weak & All & Strong & Weak \\
\hline Constant & $\begin{array}{l}-0.17 \\
(-0.29)\end{array}$ & $\begin{array}{l}-0.47 \\
(-0.58)\end{array}$ & $\begin{array}{l}-2.20 * \\
(-1.94)\end{array}$ & $\begin{array}{c}-0.77 * * \\
(-2.34)\end{array}$ & $\begin{array}{l}-0.10 \\
(-0.22)\end{array}$ & $\begin{array}{c}-1.91 * * * \\
(-3.89)\end{array}$ & $\begin{array}{l}-0.51 \\
(-1.04)\end{array}$ & $\begin{array}{c}-0.66 \\
(-0.83)\end{array}$ & $\begin{array}{l}-1.04 \\
(-1.56)\end{array}$ & $\begin{array}{l}-1.81 * \\
(-1.72)\end{array}$ & $\begin{array}{l}-1.60 \\
(-0.92)\end{array}$ & $\begin{array}{l}-0.41 \\
(-0.34)\end{array}$ \\
\hline FROM_50_TO_99 & $\begin{array}{l}0.38 * \\
(1.95)\end{array}$ & $\begin{array}{l}0.42 * \\
(1.70)\end{array}$ & $\begin{array}{c}0.31 \\
(1.01)\end{array}$ & $\begin{array}{c}0.39 * * * \\
(3.57)\end{array}$ & $\begin{array}{l}0.46 * * \\
(2.50)\end{array}$ & $\begin{array}{c}0.39 * * * \\
(3.00)\end{array}$ & $\begin{array}{c}0.11 \\
(0.73)\end{array}$ & $\begin{array}{c}0.51 \\
(1.48)\end{array}$ & $\begin{array}{l}-0.06 \\
(-0.38)\end{array}$ & $\begin{array}{l}0.42 * * \\
(2.15)\end{array}$ & $\begin{array}{c}0.99 \\
(0.87)\end{array}$ & $\begin{array}{l}0.52 * * \\
(2.34)\end{array}$ \\
\hline FULLY_INDEP & $\begin{array}{l}0.39 * * \\
(2.38)\end{array}$ & $\begin{array}{c}0.32 \\
(1.56)\end{array}$ & $\begin{array}{l}0.47 * \\
(1.76)\end{array}$ & $\begin{array}{c}0.45 * * * \\
(4.58)\end{array}$ & $\begin{array}{c}0.15 \\
(1.01)\end{array}$ & $\begin{array}{c}0.68 * * * \\
(5.03)\end{array}$ & $\begin{array}{l}0.32 * * \\
(2.02)\end{array}$ & $\begin{array}{c}0.38 \\
(1.15)\end{array}$ & $\begin{array}{c}0.32 \\
(1.55)\end{array}$ & $\begin{array}{l}0.42 * \\
(1.94)\end{array}$ & $\begin{array}{c}1.21 \\
(1.05)\end{array}$ & $\begin{array}{l}0.52 * \\
(1.76)\end{array}$ \\
\hline SUE & $\begin{array}{c}0.00 \\
(0.06)\end{array}$ & $\begin{array}{c}0.01 \\
(0.57)\end{array}$ & $\begin{array}{l}-0.05 \\
(-1.23)\end{array}$ & $\begin{array}{l}-0.00 \\
(-0.18)\end{array}$ & $\begin{array}{l}-0.01 \\
(-0.49)\end{array}$ & $\begin{array}{c}0.01 \\
(0.29)\end{array}$ & $\begin{array}{c}0.02 \\
(0.70)\end{array}$ & $\begin{array}{c}0.01 \\
(0.18)\end{array}$ & $\begin{array}{c}0.01 \\
(0.17)\end{array}$ & $\begin{array}{c}0.12 * * * \\
(3.73)\end{array}$ & $\begin{array}{c}0.25 * * * \\
(3.67)\end{array}$ & $\begin{array}{l}0.07 * * \\
(2.07)\end{array}$ \\
\hline SIZE & $\begin{array}{l}-0.00 \\
(-0.07)\end{array}$ & $\begin{array}{l}-0.03 \\
(-0.49)\end{array}$ & $\begin{array}{l}0.18 * \\
(1.93)\end{array}$ & $\begin{array}{c}0.12 * * * \\
(4.74)\end{array}$ & $\begin{array}{c}0.06 \\
(1.46)\end{array}$ & $\begin{array}{c}0.20 * * * \\
(5.27)\end{array}$ & $\begin{array}{c}0.11 * * * \\
(2.90)\end{array}$ & $\begin{array}{c}0.06 \\
(0.89)\end{array}$ & $\begin{array}{c}0.16 * * * \\
(3.02)\end{array}$ & $\begin{array}{c}0.17 * * * \\
(2.58)\end{array}$ & $\begin{array}{l}0.24 * * \\
(2.42)\end{array}$ & $\begin{array}{c}0.06 \\
(0.72)\end{array}$ \\
\hline LEVERAGE & $\begin{array}{l}-0.38 \\
(-0.85)\end{array}$ & $\begin{array}{l}-0.43 \\
(-0.76)\end{array}$ & $\begin{array}{l}-0.49 \\
(-0.80)\end{array}$ & $\begin{array}{l}-0.45 * * \\
(-2.01)\end{array}$ & $\begin{array}{c}0.11 \\
(0.34)\end{array}$ & $\begin{array}{c}-0.99 * * * \\
(-3.01)\end{array}$ & $\begin{array}{l}-0.08 \\
(-0.23)\end{array}$ & $\begin{array}{l}-0.22 \\
(-0.41)\end{array}$ & $\begin{array}{c}0.17 \\
(0.39)\end{array}$ & $\begin{array}{c}-1.10 * * \\
(-2.31)\end{array}$ & $\begin{array}{l}-0.88 \\
(-0.95)\end{array}$ & $\begin{array}{c}-1.54 * * * \\
(-2.88)\end{array}$ \\
\hline
\end{tabular}




\begin{tabular}{|c|c|c|c|c|c|c|c|c|c|c|c|c|}
\hline MTB & $\begin{array}{c}0.04 * * * \\
(3.16)\end{array}$ & $\begin{array}{l}0.04 * * \\
(2.35)\end{array}$ & $\begin{array}{l}0.06 * * \\
(2.13)\end{array}$ & $\begin{array}{c}0.01 \\
(0.61)\end{array}$ & $\begin{array}{c}0.00 \\
(0.34)\end{array}$ & $\begin{array}{c}0.01 \\
(0.25)\end{array}$ & $\begin{array}{c}0.00 \\
(0.24)\end{array}$ & $\begin{array}{l}-0.00 \\
(-0.25)\end{array}$ & $\begin{array}{c}0.03 \\
(0.86)\end{array}$ & $\begin{array}{l}-0.02 \\
(-0.67)\end{array}$ & $\begin{array}{l}-0.04 \\
(-1.37)\end{array}$ & $\begin{array}{l}-0.01 \\
(-0.19)\end{array}$ \\
\hline D_LOSS & $\begin{array}{c}-0.44 * * \\
(-2.52)\end{array}$ & $\begin{array}{c}-0.58 * * * \\
(-2.69)\end{array}$ & $\begin{array}{l}-0.10 \\
(-0.39)\end{array}$ & $\begin{array}{c}-0.39 * * * \\
(-3.62)\end{array}$ & $\begin{array}{c}-0.62 * * * \\
(-3.61)\end{array}$ & $\begin{array}{l}-0.12 \\
(-0.91)\end{array}$ & $\begin{array}{c}-0.44 * * \\
(-2.52)\end{array}$ & $\begin{array}{l}-0.44 \\
(-1.60)\end{array}$ & $\begin{array}{c}-0.49 * * \\
(-2.23)\end{array}$ & $\begin{array}{l}-0.32 \\
(-0.82)\end{array}$ & $\begin{array}{c}-0.81 * * \\
(-2.10)\end{array}$ & $\begin{array}{l}-0.16 \\
(-0.31)\end{array}$ \\
\hline BIG_4 & $\begin{array}{c}0.04 \\
(0.26)\end{array}$ & $\begin{array}{c}0.08 \\
(0.45)\end{array}$ & $\begin{array}{c}0.11 \\
(0.47)\end{array}$ & $\begin{array}{c}-0.20 * * \\
(-2.27)\end{array}$ & $\begin{array}{c}-0.13 \\
(-0.92)\end{array}$ & $\begin{array}{l}-0.26 * * \\
(-2.24)\end{array}$ & $\begin{array}{l}-0.01 \\
(-0.04)\end{array}$ & $\begin{array}{c}0.18 \\
(0.62)\end{array}$ & $\begin{array}{l}-0.09 \\
(-0.45)\end{array}$ & $\begin{array}{c}0.16 \\
(0.72)\end{array}$ & $\begin{array}{c}0.02 \\
(0.03)\end{array}$ & $\begin{array}{c}0.29 \\
(1.13)\end{array}$ \\
\hline ABN_ACC & $\begin{array}{c}-0.72 \\
(-1.20)\end{array}$ & $\begin{array}{l}-0.28 \\
(-0.42)\end{array}$ & $\begin{array}{l}-2.35 * \\
(-1.74)\end{array}$ & $\begin{array}{c}-0.18 \\
(-0.47)\end{array}$ & $\begin{array}{l}-0.34 \\
(-0.65)\end{array}$ & $\begin{array}{c}0.10 \\
(0.18)\end{array}$ & $\begin{array}{c}0.46 \\
(0.71)\end{array}$ & $\begin{array}{l}-0.55 \\
(-0.71)\end{array}$ & $\begin{array}{l}1.89 * \\
(1.92)\end{array}$ & $\begin{array}{l}-3.03 * * \\
(-2.44)\end{array}$ & $\begin{array}{l}-0.75 \\
(-0.43)\end{array}$ & $\begin{array}{c}-4.43 * * * \\
(-2.96)\end{array}$ \\
\hline REPORT_LAG & $\begin{array}{c}0.00 \\
(1.43)\end{array}$ & $\begin{array}{c}0.00 \\
(0.61)\end{array}$ & $\begin{array}{c}0.01 * * * \\
(2.60)\end{array}$ & $\begin{array}{c}0.00 \\
(0.23)\end{array}$ & $\begin{array}{c}0.00 \\
(0.58)\end{array}$ & $\begin{array}{l}-0.00 \\
(-0.14)\end{array}$ & $\begin{array}{l}-0.00 \\
(-0.70)\end{array}$ & $\begin{array}{c}0.00 \\
(0.32)\end{array}$ & $\begin{array}{l}-0.00 \\
(-1.51)\end{array}$ & $\begin{array}{c}-0.00 \\
(-0.07)\end{array}$ & $\begin{array}{c}0.00 \\
(0.05)\end{array}$ & $\begin{array}{c}-0.00 \\
(-0.53)\end{array}$ \\
\hline CROSS_LIST & $\begin{array}{c}0.84 \\
(1.58)\end{array}$ & $\begin{array}{l}-0.08 \\
(-0.24)\end{array}$ & $\begin{array}{c}0.92 \\
(1.50)\end{array}$ & $\begin{array}{c}0.05 \\
(0.25)\end{array}$ & $\begin{array}{l}0.44 * \\
(1.93)\end{array}$ & $\begin{array}{l}-0.23 \\
(-0.81)\end{array}$ & $\begin{array}{l}-0.16 \\
(-0.83)\end{array}$ & $\begin{array}{l}-0.29 \\
(-1.03)\end{array}$ & $\begin{array}{l}-0.02 \\
(-0.07)\end{array}$ & $\begin{array}{c}0.26 \\
(0.85)\end{array}$ & $\begin{array}{c}0.05 \\
(0.13)\end{array}$ & $\begin{array}{c}0.57 \\
(1.28)\end{array}$ \\
\hline EXPERIENCE & $\begin{array}{c}0.01 \\
(0.61)\end{array}$ & $\begin{array}{c}0.03 \\
(1.43)\end{array}$ & $\begin{array}{l}-0.03 \\
(-1.08)\end{array}$ & $\begin{array}{c}0.01 \\
(1.11)\end{array}$ & $\begin{array}{l}-0.01 \\
(-0.42)\end{array}$ & $\begin{array}{c}0.02 \\
(1.42)\end{array}$ & $\begin{array}{l}-0.00 \\
(-0.05)\end{array}$ & $\begin{array}{c}0.04 \\
(1.28)\end{array}$ & $\begin{array}{l}-0.01 \\
(-0.56)\end{array}$ & $\begin{array}{c}0.02 \\
(0.77)\end{array}$ & $\begin{array}{c}0.00 \\
(0.05)\end{array}$ & $\begin{array}{c}0.01 \\
(0.28)\end{array}$ \\
\hline BOARD_SIZE & $\begin{array}{c}0.02 \\
(0.56)\end{array}$ & $\begin{array}{l}0.08 * \\
(1.78)\end{array}$ & $\begin{array}{l}-0.01 \\
(-0.24)\end{array}$ & $\begin{array}{c}-0.05 * * * \\
(-3.24)\end{array}$ & $\begin{array}{c}0.01 \\
(0.29)\end{array}$ & $\begin{array}{l}-0.04 * * \\
(-2.36)\end{array}$ & $\begin{array}{l}-0.02 \\
(-1.38)\end{array}$ & $\begin{array}{c}0.02 \\
(0.53)\end{array}$ & $\begin{array}{l}-0.03 \\
(-1.54)\end{array}$ & $\begin{array}{l}-0.03 \\
(-0.99)\end{array}$ & $\begin{array}{l}-0.15 * * \\
(-2.29)\end{array}$ & $\begin{array}{l}-0.01 \\
(-0.36)\end{array}$ \\
\hline Time FE & YES & YES & YES & YES & YES & YES & YES & YES & YES & YES & YES & YES \\
\hline Industry FE & YES & YES & YES & YES & YES & YES & YES & YES & YES & YES & YES & YES \\
\hline Cluster & Firm & Firm & Firm & Firm & Firm & Firm & Firm & Firm & Firm & Firm & Firm & Firm \\
\hline Observations & 1,410 & 964 & 446 & 3,642 & 1,884 & 1,758 & 1,554 & 728 & 826 & 530 & 207 & 323 \\
\hline R-squared & 0.04 & 0.05 & 0.09 & 0.05 & 0.04 & 0.08 & 0.06 & 0.05 & 0.09 & 0.11 & 0.21 & 0.14 \\
\hline F-statistic & 1.679 & 1.594 & 2.178 & 4.904 & 2.911 & 3.949 & 2.529 & 1.203 & 2.902 & 2.935 & 5.033 & 2.378 \\
\hline
\end{tabular}


Table 10. Impact of the AC's independence on the market reaction: additional test with the World Bank's governance index

This table reports the results of the tests of models 2 and 3 using the abnormal returns variance (AVAR) and the abnormal trading volume (AVOL) as measures of market reaction. INDEP_AC is the percentage of independent members in the audit committee. RULE_OF_LAW is the 2006-2014 average of the World Bank's governance index (rule of law item). REGUL_QUALITY is the 2006-2014 average of the World Bank's governance index (regulatory quality item). OVERALL_INDEX is the average of the two items RULE_OF_LAW and REGUL_QUALITY. SUE is the ratio of the absolute surprise divided by the standard deviation of analysts' estimates. SIZE is the natural logarithm of total assets in euros. LEVERAGE is the ratio of total liabilities divided by total assets. MTB is the market value of equity divided by the book value of equity. D_LOSS is a dummy variable that takes the value 1 if the EPS is negative, and 0 otherwise. BIG_4 is a dummy variable that takes the value 1 if the announcing firm's auditor is a Big 4 and 0 otherwise. ABN_ACC equals to the residuals (the abnormal accruals) of a total normal accruals model following Francis et al. (2013). REPORT_LAG is the number of days between fiscal year end and the announcement date for a given year. CROSS_LIST is a dummy variable that is equal to 1 if the announcing firm is listed in the US and 0 otherwise. EXPERIENCE is the median number of years for all audit committee members spent on the board of the announcing firm. AC_SIZE is the number

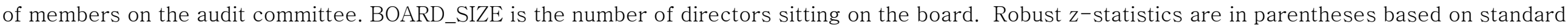
errors adjusted for heteroscedasticity and firm-level clustering. *, ** and $* * *$ represents statistical significance at the $10 \%, 5 \%$ and $1 \%$ thresholds.

\begin{tabular}{|c|c|c|c|c|c|c|c|c|c|c|c|c|}
\hline & $\begin{array}{c}(1) \\
\text { AVAR }\end{array}$ & $\begin{array}{c}(2) \\
\text { AVOL }\end{array}$ & $\begin{array}{c}(3) \\
\text { AVAR }\end{array}$ & $\begin{array}{c}(4) \\
\text { AVOL }\end{array}$ & $\begin{array}{c}(5) \\
\text { AVAR }\end{array}$ & $\begin{array}{c}(6) \\
\text { AVOL }\end{array}$ & $\begin{array}{c}(7) \\
\text { AVAR }\end{array}$ & $\begin{array}{c}(8) \\
\text { AVOL }\end{array}$ & $\begin{array}{c}(9) \\
\text { AVAR }\end{array}$ & $\begin{array}{l}(10) \\
\text { AVOL }\end{array}$ & $\begin{array}{c}(11) \\
\text { AVAR }\end{array}$ & $\begin{array}{l}(12) \\
\text { AVOL }\end{array}$ \\
\hline CONSTANT & $\begin{array}{c}- \\
1.77 * * * \\
(-5.88)\end{array}$ & $\begin{array}{c}- \\
2.47 * * * \\
(-4.85)\end{array}$ & $\begin{array}{l}3.34 * * * \\
(12.15)\end{array}$ & $\begin{array}{c}2.82 * * * \\
(6.71)\end{array}$ & $\begin{array}{c}- \\
1.95 * * * \\
(-6.33)\end{array}$ & $\begin{array}{c}- \\
2.67 * * * \\
(-5.19)\end{array}$ & $\begin{array}{l}3.22 * * * \\
(11.50)\end{array}$ & $\begin{array}{c}2.79 * * * \\
(6.44)\end{array}$ & $\begin{array}{c}- \\
1.95 * * * \\
(-6.30)\end{array}$ & $\begin{array}{c}- \\
2.72 * * * \\
(-5.20)\end{array}$ & $\begin{array}{l}3.20 * * * \\
(11.56)\end{array}$ & $\begin{array}{c}2.69 * * * \\
(6.27)\end{array}$ \\
\hline INDEP_AC & $\begin{array}{c}0.40 * * * \\
(5.27)\end{array}$ & $\begin{array}{l}1.31 * * \\
(2.39)\end{array}$ & $\begin{array}{l}0.14 * \\
(1.81)\end{array}$ & $\begin{array}{l}0.81 * \\
(1.96)\end{array}$ & $\begin{array}{c}0.35 * * * \\
(4.50)\end{array}$ & $\begin{array}{l}1.31 * * \\
(2.40)\end{array}$ & $\begin{array}{l}0.09 \\
(1.12)\end{array}$ & $\begin{array}{c}0.65 \\
(1.47)\end{array}$ & $\begin{array}{c}0.37 * * * \\
(4.87)\end{array}$ & $\begin{array}{l}1.39 * * \\
(2.45)\end{array}$ & $\begin{array}{c}0.11 \\
(1.45)\end{array}$ & $\begin{array}{l}0.77 * \\
(1.77)\end{array}$ \\
\hline $\begin{array}{l}\text { RULE_OF_LAW } \\
\text { INDEP_AC * RULE_OF_LAW }\end{array}$ & $\begin{array}{c}0.62 * * * \\
(5.29)\end{array}$ & $\begin{array}{l}1.02 * * * \\
(3.93) \\
-0.54 * \\
(-1.66)\end{array}$ & $\begin{array}{c}0.59 * * * \\
(7.54)\end{array}$ & $\begin{array}{l}0.88 * * * \\
(4.30) \\
-0.40 \\
(-1.59)\end{array}$ & & & & & & & & \\
\hline REGUL_QUALITY & & & & & $\begin{array}{c}0.68 * * * \\
(5.92)\end{array}$ & $\begin{array}{l}1.11 * * * \\
(4.11)\end{array}$ & $\begin{array}{l}0.62 * * * \\
(7.00)\end{array}$ & $\begin{array}{c}0.87 * * * \\
(3.75)\end{array}$ & & & & \\
\hline $\begin{array}{l}\text { INDEP_AC * } \\
\text { REGUL_QUALITY }\end{array}$ & & & & & & $\begin{array}{l}-0.61 * \\
(-1.77)\end{array}$ & & $\begin{array}{l}-0.35 \\
(-1.22)\end{array}$ & & & & \\
\hline $\begin{array}{l}\text { OVERALL_INDEX } \\
\text { INDEP_AC } * \text { OVERALL_INDEX }\end{array}$ & & & & & & & & & $\begin{array}{l}0.69 * * * \\
(5.82)\end{array}$ & $\begin{array}{l}1.15 * * * \\
(4.23) \\
-0.62 *\end{array}$ & $\begin{array}{c}0.65 * * * \\
(7.69)\end{array}$ & $\begin{array}{c}0.94 * * * \\
(4.24) \\
-0.40\end{array}$ \\
\hline
\end{tabular}


SUE

SIZE

LEVERAGE

MTB

D_LOSS

BIG_4

ABN_ACC

REPORT_LAG

CROSS_LIST

EXPERIENCE

AC_SIZE

BOARD_SIZE

Time FE

Industry FE

Cluster

Observations

R-squared

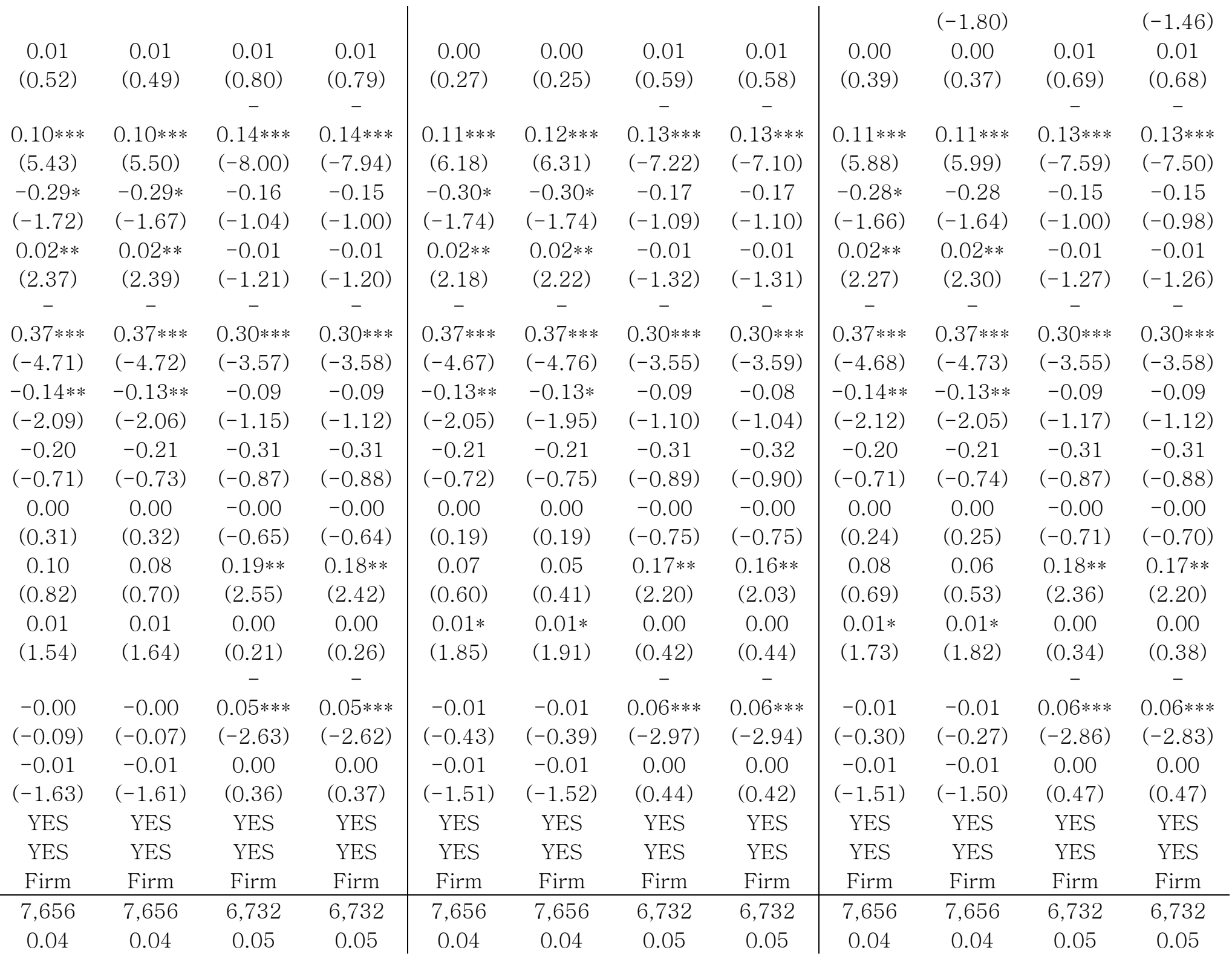


Table 11. Impact of the AC's independence on the market reaction in different institutional contexts

This table reports the results of the tests of models 1 using the abnormal returns variance (AVAR) and the abnormal trading volume (AVOL) as measures of market reaction. The "Strong institutions" subsample is composed of firms in countries with World Bank's governance OVERALL_INDEX above the sample median, while the "Weak institutions" subsample includes firms in countries an overall index equal or below the sample median. INDEP_AC is the percentage of independent members in the audit committee. SUE is the ratio of the absolute surprise divided by the standard deviation of analysts' estimates. SIZE is the natural logarithm of total assets in euros. LEVERAGE is the ratio of total liabilities divided by total assets. MTB is the market value of equity divided by the book value of equity. D_LOSS is a dummy variable that takes the value 1 if the EPS is negative, and 0 otherwise. BIG_4 is a dummy variable that takes the value 1 if the announcing firm's auditor is a Big 4 and 0 otherwise. ABN_ACC equals to the residuals (the abnormal accruals) of a total normal accruals model following Francis et al. (2013). REPORT_LAG is the number of days between fiscal year end and the announcement date for a given year. CROSS_LIST is a dummy variable that is equal to 1 if the announcing firm is listed in the US and 0 otherwise. EXPERIENCE is the median number of years for all audit committee members spent on the board of the announcing firm. AC_SIZE is the number of members on the audit committee. BOARD_SIZE is the number of directors sitting on the board. Robust $z$-statistics are in parentheses based on standard errors adjusted for heteroscedasticity and firm-level clustering. *, ** and $* * *$ represents statistical significance at the $10 \%, 5 \%$ and $1 \%$ thresholds.

\begin{tabular}{|c|c|c|c|c|c|c|}
\hline & \multicolumn{2}{|c|}{$\begin{array}{c}\text { Full } \\
\text { sample }\end{array}$} & \multicolumn{2}{|c|}{$\begin{array}{c}\text { Strong } \\
\text { institutions }\end{array}$} & \multicolumn{2}{|c|}{$\begin{array}{c}\text { Weak } \\
\text { institutions }\end{array}$} \\
\hline & $\begin{array}{c}\text { (1) } \\
\text { AVAR }\end{array}$ & $\begin{array}{c}(2) \\
\text { AVOL }\end{array}$ & $\begin{array}{c}(3) \\
\text { AVAR }\end{array}$ & $\begin{array}{c}(4) \\
\text { AVOL }\end{array}$ & $\begin{array}{c}(5) \\
\text { AVAR }\end{array}$ & $\begin{array}{c}(6) \\
\text { AVOL }\end{array}$ \\
\hline Constant & $\begin{array}{l}-0.66 * * * \\
(-2.89)\end{array}$ & $\begin{array}{l}4.39 * * * \\
(16.80)\end{array}$ & $\begin{array}{l}-0.49 * \\
(-1.66)\end{array}$ & $\begin{array}{l}4.65 * * * \\
(12.67)\end{array}$ & $\begin{array}{l}-1.69 * * * \\
(-4.50)\end{array}$ & $\begin{array}{l}3.43 * * * \\
(9.13)\end{array}$ \\
\hline INDEP_AC & $\begin{array}{c}0.41 * * * \\
(5.32)\end{array}$ & $\begin{array}{l}0.15 * \\
(1.88)\end{array}$ & $\begin{array}{c}0.15 \\
(1.15)\end{array}$ & $\begin{array}{c}0.04 \\
(0.29)\end{array}$ & $\begin{array}{c}0.29 * * * \\
(2.76)\end{array}$ & $\begin{array}{c}0.06 \\
(0.65)\end{array}$ \\
\hline SUE & $\begin{array}{c}0.01 \\
(0.51)\end{array}$ & $\begin{array}{c}0.01 \\
(0.75)\end{array}$ & $\begin{array}{l}0.00 \\
(0.24)\end{array}$ & $\begin{array}{c}0.01 \\
(0.52)\end{array}$ & $\begin{array}{l}-0.00 \\
(-0.22)\end{array}$ & $\begin{array}{c}0.00 \\
(0.17)\end{array}$ \\
\hline SIZE & $\begin{array}{c}0.09 * * * \\
(4.95)\end{array}$ & $\begin{array}{c}-0.15 * * * \\
(-8.14)\end{array}$ & $\begin{array}{c}0.08 * * * \\
(3.17)\end{array}$ & $\begin{array}{c}-0.15 * * * \\
(-5.48)\end{array}$ & $\begin{array}{c}0.16 * * * \\
(5.40)\end{array}$ & $\begin{array}{c}-0.08 * * * \\
(-2.80)\end{array}$ \\
\hline LEVERAGE & $\begin{array}{c}-0.44 * * * \\
(-2.59)\end{array}$ & $\begin{array}{l}-0.29 * \\
(-1.92)\end{array}$ & $\begin{array}{c}-0.07 \\
(-0.31)\end{array}$ & $\begin{array}{c}0.03 \\
(0.12)\end{array}$ & $\begin{array}{c}-0.75 * * * \\
(-3.18)\end{array}$ & $\begin{array}{c}-0.64 * * * \\
(-3.32)\end{array}$ \\
\hline MTB & $\begin{array}{l}0.02 * * \\
(2.37)\end{array}$ & $\begin{array}{c}-0.01 \\
(-1.16)\end{array}$ & $\begin{array}{c}0.01 \\
(1.12)\end{array}$ & $\begin{array}{l}-0.01 \\
(-0.81)\end{array}$ & $\begin{array}{l}0.04 * * \\
(2.30)\end{array}$ & $\begin{array}{l}-0.01 \\
(-0.43)\end{array}$ \\
\hline D_LOSS & $\begin{array}{c}-0.39 * * * \\
(-4.87)\end{array}$ & $\begin{array}{c}-0.31 * * * \\
(-3.73)\end{array}$ & $\begin{array}{c}-0.49 * * * \\
(-4.20)\end{array}$ & $\begin{array}{c}-0.45 * * * \\
(-3.39)\end{array}$ & $\begin{array}{l}-0.13 \\
(-1.34)\end{array}$ & $\begin{array}{l}-0.03 \\
(-0.35)\end{array}$ \\
\hline BIG_4 & $\begin{array}{l}-0.09 \\
(-1.44)\end{array}$ & $\begin{array}{l}-0.05 \\
(-0.60)\end{array}$ & $\begin{array}{l}-0.11 \\
(-1.21)\end{array}$ & $\begin{array}{c}0.03 \\
(0.22)\end{array}$ & $\begin{array}{l}-0.11 \\
(-1.21)\end{array}$ & $\begin{array}{l}-0.15 * \\
(-1.65)\end{array}$ \\
\hline ABN_ACC & $\begin{array}{l}-0.23 \\
(-0.81)\end{array}$ & $\begin{array}{l}-0.33 \\
(-0.92)\end{array}$ & $\begin{array}{l}-0.30 \\
(-0.85)\end{array}$ & $\begin{array}{c}-0.14 \\
(-0.28)\end{array}$ & $\begin{array}{c}0.07 \\
(0.16)\end{array}$ & $\begin{array}{l}-0.43 \\
(-0.99)\end{array}$ \\
\hline REPORT_LAG & $\begin{array}{l}0.00 \\
(0.38)\end{array}$ & $\begin{array}{l}-0.00 \\
(-0.58)\end{array}$ & $\begin{array}{c}0.00 \\
(0.78)\end{array}$ & $\begin{array}{c}-0.00 \\
(-0.49)\end{array}$ & $\begin{array}{l}-0.00 \\
(-0.69)\end{array}$ & $\begin{array}{c}-0.00 \\
(-0.54)\end{array}$ \\
\hline CROSS_LIST & $\begin{array}{c}0.11 \\
(0.93)\end{array}$ & $\begin{array}{l}0.20 * * \\
(2.55)\end{array}$ & $\begin{array}{l}-0.16 \\
(-0.91)\end{array}$ & $\begin{array}{c}0.15 \\
(1.22)\end{array}$ & $\begin{array}{c}0.12 \\
(0.74)\end{array}$ & $\begin{array}{c}0.13 \\
(1.34)\end{array}$ \\
\hline EXPERIENCE & $\begin{array}{c}0.01 \\
(1.16)\end{array}$ & $\begin{array}{l}-0.00 \\
(-0.06)\end{array}$ & $\begin{array}{c}0.01 \\
(1.43)\end{array}$ & $\begin{array}{c}0.02 \\
(1.21)\end{array}$ & $\begin{array}{c}0.01 \\
(1.26)\end{array}$ & $\begin{array}{c}-0.01 \\
(-0.71)\end{array}$ \\
\hline AC_SIZE & $\begin{array}{c}0.01 \\
(0.34)\end{array}$ & $\begin{array}{c}-0.04 * * \\
(-2.08)\end{array}$ & $\begin{array}{l}-0.04 \\
(-1.28)\end{array}$ & $\begin{array}{c}-0.10 * * * \\
(-2.97)\end{array}$ & $\begin{array}{c}0.02 \\
(0.43)\end{array}$ & $\begin{array}{c}-0.02 \\
(-0.65)\end{array}$ \\
\hline
\end{tabular}




\begin{tabular}{l|cc|cc|cc} 
BOARD_SIZE & $-0.02 * *$ & -0.00 & 0.03 & -0.01 & -0.02 & -0.00 \\
& $(-2.41)$ & $(-0.53)$ & $(1.63)$ & $(-0.58)$ & $(-1.59)$ & $(-0.04)$ \\
Time FE & YES & YES & YES & YES & YES & YES \\
Industry FE & YES & YES & YES & YES & YES & YES \\
Cluster & Firm & Firm & Firm & Firm & Firm & Firm \\
\hline Observations & 7,656 & 6,732 & 4,255 & 3,688 & 3,401 & 3,044 \\
R-squared & 0.04 & 0.04 & 0.04 & 0.05 & 0.05 & 0.04 \\
F-statistic & $7.385 * * *$ & $9.045 * * *$ & $5.463 * * *$ & $6.011 * * *$ & $4.935 * * *$ & $4.335 * * *$ \\
\hline
\end{tabular}




\section{Table 12. Impact of the AC's independence on the market reaction with control for AC's composition (2SLS regression)}

This table reports the tests of model 1 using two-stage least square regression. The dependent variables are the percentage of independent members in the audit committee in the first stages regressions, and the market reaction measures (AVAR and AVOL) in the second stage regressions. The percentage of independent members in the AC is instrumentalized in the second stage with the OWNERSHIP variable (the percentage of closely held shares). The "Strong institutions" subsample is composed of firms in countries with Brown et al. total index above the sample median, while the "Weak institutions" subsample includes firms in countries with Brown et al. total index equal or below the sample median. SUE is the ratio of the absolute surprise divided by the standard deviation of analysts' estimates. SIZE is the natural logarithm of total assets in euros. LEVERAGE is the ratio of total liabilities divided by total assets. MTB is the market value of equity divided by the book value of equity. D_LOSS is a dummy variable that takes the value 1 if the EPS is negative, and 0 otherwise. BIG_4 is a dummy variable that takes the value of 1 if the announcing firm's auditor is a Big 4, and 0 otherwise. ABN_ACC equals to the residuals (the abnormal accruals) of a total normal accruals model following Francis et al. (2013). REPORT_LAG is the number of days between fiscal year end and the announcement date for a given year. CROSS_LIST is a dummy variable that is equal to 1 if the announcing firm is listed in the US, and 0 otherwise. EXPERIENCE is the median number of years for all audit committee members spent on the board of the announcing firm. AC_SIZE is the number of members on the audit committee. BOARD_SIZE is the number of directors sitting on the board. Robust $\mathrm{z}$-statistics are in parentheses based on standard errors adjusted for heteroscedasticity and firm-level clustering. *,** and $* * *$ represents statistical significance at the $10 \%$, 5\% and $1 \%$ thresholds

\begin{tabular}{|c|c|c|c|c|c|c|c|c|c|c|c|c|}
\hline & \multicolumn{4}{|c|}{ Full sample } & \multicolumn{4}{|c|}{ Strong institutions } & \multicolumn{4}{|c|}{ Weak institutions } \\
\hline Stage & $\begin{array}{c}(1) \\
\text { First }\end{array}$ & $\begin{array}{c}(2) \\
\text { Second }\end{array}$ & \begin{tabular}{|c|} 
(3) \\
First \\
\end{tabular} & $\begin{array}{c}(4) \\
\text { Second }\end{array}$ & $\begin{array}{c}(5) \\
\text { First }\end{array}$ & $\begin{array}{c}\text { (6) } \\
\text { Second }\end{array}$ & \begin{tabular}{|c|}
$(7)$ \\
First \\
\end{tabular} & $\begin{array}{c}(8) \\
\text { Second }\end{array}$ & $\begin{array}{c}(9) \\
\text { First }\end{array}$ & $\begin{array}{c}(10) \\
\text { Second }\end{array}$ & $\begin{array}{c}(11) \\
\text { First } \\
\end{array}$ & $\begin{array}{l}(12) \\
\text { Second }\end{array}$ \\
\hline $\begin{array}{c}\text { Dependent } \\
\text { Variables }\end{array}$ & INDEP_AC & AVAR & INDEP_AC & AVOL & INDEP_AC & AVAR & INDEP_AC & AVOL & INDEP_AC & AVAR & INDEP_AC & AVOL \\
\hline Constant & $\begin{array}{l}0.54 * * * \\
(13.64)\end{array}$ & $\begin{array}{c}-1.65 * * * \\
(-5.86)\end{array}$ & $\begin{array}{l}0.53 * * * \\
(12.56)\end{array}$ & $\begin{array}{l}4.09 * * * \\
(12.91)\end{array}$ & $\begin{array}{c}0.70 * * * \\
(11.50)\end{array}$ & $\begin{array}{l}-0.54 \\
(-1.32)\end{array}$ & $\begin{array}{l}0.71 * * * \\
(11.02)\end{array}$ & $\begin{array}{c}5.01 * * * \\
(9.97)\end{array}$ & $\begin{array}{c}0.34 * * * \\
(5.70)\end{array}$ & $\begin{array}{c}-3.42 * * * \\
(-4.03)\end{array}$ & $\begin{array}{c}0.33 * * * \\
(5.32)\end{array}$ & $\begin{array}{c}2.70 * * * \\
(5.35)\end{array}$ \\
\hline INDEP_AC & & $\begin{array}{c}2.85 * * * \\
(7.24)\end{array}$ & & $\begin{array}{l}0.92 * * \\
(2.18)\end{array}$ & & $\begin{array}{l}1.39 * * \\
(2.44)\end{array}$ & & $\begin{array}{c}-0.28 \\
(-0.48)\end{array}$ & & $\begin{array}{c}6.08 * * * \\
(3.53)\end{array}$ & & $\begin{array}{c}2.78 * * \\
(2.41)\end{array}$ \\
\hline OWNERSHIP & $\begin{array}{l}-0.00 * * * \\
(-14.96)\end{array}$ & & $\begin{array}{c}-0.00 * * * \\
(-13.60)\end{array}$ & & $\begin{array}{c}-0.00 * * * \\
(-11.12)\end{array}$ & & $\begin{array}{l}-0.00 * * * \\
(-10.58)\end{array}$ & & $\begin{array}{c}-0.00 * * * \\
(-6.96)\end{array}$ & & $\begin{array}{c}-0.00 * * * \\
(-6.08)\end{array}$ & \\
\hline SUE & $\begin{array}{c}0.00 \\
(1.56)\end{array}$ & $\begin{array}{c}-0.01 \\
(-0.44)\end{array}$ & $\begin{array}{c}0.00 * * \\
(2.00)\end{array}$ & $\begin{array}{c}0.01 \\
(0.42)\end{array}$ & $\begin{array}{c}0.00 \\
(1.00)\end{array}$ & $\begin{array}{c}0.00 \\
(0.27)\end{array}$ & $\begin{array}{c}0.00 \\
(1.42)\end{array}$ & $\begin{array}{c}0.02 \\
(0.90)\end{array}$ & $\begin{array}{c}0.00 \\
(0.18)\end{array}$ & $\begin{array}{l}-0.01 \\
(-0.32)\end{array}$ & $\begin{array}{c}0.00 \\
(0.34)\end{array}$ & $\begin{array}{c}-0.01 \\
(-0.27)\end{array}$ \\
\hline SIZE & $\begin{array}{c}-0.05 * * * \\
(-3.54)\end{array}$ & $\begin{array}{c}-0.28 * * * \\
(-3.44)\end{array}$ & $\begin{array}{c}-0.04 * * * \\
(-3.10)\end{array}$ & $\begin{array}{c}-0.28 * * * \\
(-3.16)\end{array}$ & $\begin{array}{c}-0.10 * * * \\
(-5.02)\end{array}$ & $\begin{array}{c}-0.47 * * * \\
(-3.36)\end{array}$ & $\begin{array}{c}-0.10 * * * \\
(-4.67)\end{array}$ & $\begin{array}{c}-0.51 * * * \\
(-3.45)\end{array}$ & $\begin{array}{c}0.00 \\
(0.26)\end{array}$ & $\begin{array}{l}-0.22 \\
(-1.36)\end{array}$ & $\begin{array}{c}0.00 \\
(0.24)\end{array}$ & $\begin{array}{l}-0.11 \\
(-1.01)\end{array}$ \\
\hline LEVERAGE & $0.04 * * *$ & -0.03 & $0.05 * * *$ & $-0.19 * * *$ & $0.01 * * *$ & 0.01 & $0.01 * *$ & $-0.16 * * *$ & $0.05 * * *$ & -0.12 & $0.05 * * *$ & $-0.22 * * *$ \\
\hline
\end{tabular}




\begin{tabular}{|c|c|c|c|c|c|c|c|c|c|c|c|c|}
\hline & (14.78) & $(-1.11)$ & $(14.58)$ & $(-6.64)$ & $(2.70)$ & $(0.22)$ & $(2.28)$ & $(-4.78)$ & (12.80) & $(-1.11)$ & (12.61) & $(-3.10)$ \\
\hline MTB & $\begin{array}{c}-0.05 * * \\
(-1.96)\end{array}$ & $\begin{array}{c}-0.26 \\
(-1.63)\end{array}$ & $\begin{array}{l}-0.05 * \\
(-1.95)\end{array}$ & $\begin{array}{c}-0.24 \\
(-1.48)\end{array}$ & $\begin{array}{c}-0.08 * * \\
(-2.33)\end{array}$ & $\begin{array}{c}-0.08 \\
(-0.28)\end{array}$ & $\begin{array}{c}-0.10 * * \\
(-2.45)\end{array}$ & $\begin{array}{c}-0.05 \\
(-0.22)\end{array}$ & $\begin{array}{c}0.02 \\
(0.47)\end{array}$ & $\begin{array}{c}-0.72 \\
(-1.57)\end{array}$ & $\begin{array}{c}0.02 \\
(0.53)\end{array}$ & $\begin{array}{c}-0.60 * * \\
(-2.27)\end{array}$ \\
\hline D_LOSS & $\begin{array}{c}0.00 \\
(0.59)\end{array}$ & $\begin{array}{l}0.01 * \\
(1.66)\end{array}$ & $\begin{array}{c}0.00 \\
(0.28)\end{array}$ & $\begin{array}{c}-0.01 \\
(-1.29)\end{array}$ & $\begin{array}{c}-0.00 \\
(-0.71)\end{array}$ & $\begin{array}{c}0.01 * \\
(1.79)\end{array}$ & $\begin{array}{c}-0.00 \\
(-0.80)\end{array}$ & $\begin{array}{c}-0.01 \\
(-0.56)\end{array}$ & $\begin{array}{c}0.00 \\
(0.49)\end{array}$ & $\begin{array}{c}0.02 \\
(0.71)\end{array}$ & $\begin{array}{c}0.00 \\
(0.15)\end{array}$ & $\begin{array}{c}-0.01 \\
(-0.82)\end{array}$ \\
\hline BIG_4 & $\begin{array}{c}0.00 * * * \\
(3.03)\end{array}$ & $\begin{array}{c}-0.00 \\
(-0.73)\end{array}$ & $\begin{array}{c}0.00 * * * \\
(3.41)\end{array}$ & $\begin{array}{c}-0.00 \\
(-0.86)\end{array}$ & $\begin{array}{c}0.00 * * * \\
(2.74)\end{array}$ & $\begin{array}{c}0.00 \\
(0.57)\end{array}$ & $\begin{array}{c}0.00 * * * \\
(2.86)\end{array}$ & $\begin{array}{c}-0.00 \\
(-0.19)\end{array}$ & $\begin{array}{c}0.00 * * \\
(2.22)\end{array}$ & $\begin{array}{c}-0.00 \\
(-1.24)\end{array}$ & $\begin{array}{c}0.00 * * \\
(2.57)\end{array}$ & $\begin{array}{c}-0.00 \\
(-0.95)\end{array}$ \\
\hline ABN_ACC & $\begin{array}{c}0.11 * * * \\
(7.12)\end{array}$ & $\begin{array}{c}-0.23 * * \\
(-2.01)\end{array}$ & $\begin{array}{c}0.11 * * * \\
(6.62)\end{array}$ & $\begin{array}{c}0.09 \\
(0.85)\end{array}$ & $\begin{array}{c}0.03 * * \\
(2.00)\end{array}$ & $\begin{array}{c}0.09 \\
(0.52)\end{array}$ & $\begin{array}{c}0.04 * * * \\
(2.59)\end{array}$ & $\begin{array}{c}0.29 * * \\
(2.31)\end{array}$ & $\begin{array}{c}0.14 * * * \\
(5.57)\end{array}$ & $\begin{array}{c}-0.88 * * \\
(-2.13)\end{array}$ & $\begin{array}{c}0.13 * * * \\
(5.16)\end{array}$ & $\begin{array}{c}-0.28 \\
(-1.09)\end{array}$ \\
\hline REPORT_LAG & $\begin{array}{c}-0.05 \\
(-0.87)\end{array}$ & $\begin{array}{c}-0.13 \\
(-0.41)\end{array}$ & $\begin{array}{c}-0.04 \\
(-0.63)\end{array}$ & $\begin{array}{c}-0.31 \\
(-0.86)\end{array}$ & $\begin{array}{l}-0.12 * \\
(-1.67)\end{array}$ & $\begin{array}{c}-0.23 \\
(-0.61)\end{array}$ & $\begin{array}{c}-0.08 \\
(-1.04)\end{array}$ & $\begin{array}{c}-0.51 \\
(-1.00)\end{array}$ & $\begin{array}{c}0.08 \\
(0.99)\end{array}$ & $\begin{array}{c}-0.43 \\
(-0.59)\end{array}$ & $\begin{array}{c}0.03 \\
(0.33)\end{array}$ & $\begin{array}{c}-0.01 \\
(-0.01)\end{array}$ \\
\hline CROSS_LIST & $\begin{array}{c}0.06 * * * \\
(5.46)\end{array}$ & $\begin{array}{c}-0.28 * * * \\
(-4.04)\end{array}$ & $\begin{array}{c}0.06 * * * \\
(4.86)\end{array}$ & $\begin{array}{c}-0.10 \\
(-1.21)\end{array}$ & $\begin{array}{c}0.08 * * * \\
(4.83)\end{array}$ & $\begin{array}{c}-0.16 \\
(-1.42)\end{array}$ & $\begin{array}{c}0.08 * * * \\
(4.62)\end{array}$ & $\begin{array}{c}0.03 \\
(0.23)\end{array}$ & $\begin{array}{c}0.04 * * * \\
(2.69)\end{array}$ & $\begin{array}{l}-0.35 * \\
(-1.91)\end{array}$ & $\begin{array}{c}0.04 * * \\
(2.37)\end{array}$ & $\begin{array}{c}-0.18 \\
(-1.47)\end{array}$ \\
\hline EXPERIENCE & $\begin{array}{c}-0.01 * * * \\
(-8.98)\end{array}$ & $\begin{array}{c}0.04 * * * \\
(4.69)\end{array}$ & $\begin{array}{c}-0.01 * * * \\
(-9.22)\end{array}$ & $\begin{array}{c}0.01 \\
(0.93)\end{array}$ & $\begin{array}{c}-0.01 * * * \\
(-7.36)\end{array}$ & $\begin{array}{c}0.03 * * \\
(2.10)\end{array}$ & $\begin{array}{c}-0.02 * * * \\
(-7.52)\end{array}$ & $\begin{array}{c}0.01 \\
(0.68)\end{array}$ & $\begin{array}{c}-0.01 * * * \\
(-3.62)\end{array}$ & $\begin{array}{c}0.04 \\
(1.51)\end{array}$ & $\begin{array}{c}-0.01 * * * \\
(-4.08)\end{array}$ & $\begin{array}{c}0.01 \\
(0.26)\end{array}$ \\
\hline AC_SIZE & $\begin{array}{c}-0.00 \\
(-0.55)\end{array}$ & $\begin{array}{c}0.00 \\
(0.13)\end{array}$ & $\begin{array}{c}-0.00 \\
(-0.86)\end{array}$ & $\begin{array}{c}-0.05 * * \\
(-2.08)\end{array}$ & $\begin{array}{c}-0.00 \\
(-0.65)\end{array}$ & $\begin{array}{c}-0.06 \\
(-1.55)\end{array}$ & $\begin{array}{c}-0.01 \\
(-0.94)\end{array}$ & $\begin{array}{c}-0.12 * * * \\
(-2.76)\end{array}$ & $\begin{array}{c}-0.01 \\
(-1.64)\end{array}$ & $\begin{array}{c}0.08 \\
(1.36)\end{array}$ & $\begin{array}{l}-0.01 * \\
(-1.69)\end{array}$ & $\begin{array}{c}0.02 \\
(0.53)\end{array}$ \\
\hline BOARD_SIZE & $\begin{array}{c}-0.04 * * * \\
(-25.73)\end{array}$ & $\begin{array}{c}0.08 * * * \\
(4.33)\end{array}$ & $\begin{array}{c}-0.04 * * * \\
(-24.48)\end{array}$ & $\begin{array}{c}0.03 \\
(1.42)\end{array}$ & $\begin{array}{c}0.01 * * * \\
(4.25)\end{array}$ & $\begin{array}{c}0.02 \\
(0.85)\end{array}$ & $\begin{array}{c}0.02 * * * \\
(4.58)\end{array}$ & $\begin{array}{c}-0.00 \\
(-0.05)\end{array}$ & $\begin{array}{l}-0.04 * * * \\
(-25.13)\end{array}$ & $\begin{array}{c}0.20 * * * \\
(2.58)\end{array}$ & $\begin{array}{l}-0.04 * * * \\
(-24.05)\end{array}$ & $\begin{array}{l}0.10 * \\
(1.94)\end{array}$ \\
\hline Time FE & YES & YES & YES & YES & YES & YES & YES & YES & YES & YES & YES & YES \\
\hline Industry FE & YES & YES & YES & YES & YES & YES & YES & YES & YES & YES & YES & YES \\
\hline Cluster & Firm & Firm & Firm & Firm & Firm & Firm & Firm & Firm & Firm & Firm & Firm & Firm \\
\hline $\begin{array}{l}\text { Observations } \\
\mathrm{R} \text {-squared } \\
\text { F-Statistic } \\
\text { Chi-squared }\end{array}$ & $241.0 * * *$ & $\begin{array}{c}7,634 \\
0.19 \\
74.96 * * *\end{array}$ & $240.5 * * *$ & $\begin{array}{c}6,712 \\
0.20 \\
66.07 * * *\end{array}$ & $100.1 * * *$ & $\begin{array}{c}3,912 \\
0.19 \\
34.03 * * *\end{array}$ & $173.5 * * *$ & $\begin{array}{c}3,347 \\
0.19 \\
29.61 * * *\end{array}$ & $61.0 * * *$ & $\begin{array}{c}3,722 \\
0.22 \\
43.90 * * *\end{array}$ & $90.2 * * *$ & $\begin{array}{c}3,365 \\
0.22 \\
40.38 * * *\end{array}$ \\
\hline
\end{tabular}

